Published in final edited form as:

Prog Neurobiol. 2007 April ; 81(5-6): 253-271.

\title{
The Corticostriatal Pathway in Huntington's Disease
}

\author{
Carlos Cepeda, Nanping Wu, Véronique M. André, Damian M. Cummings, and Michael S. \\ Levine \\ Mental Retardation Research Center, David Geffen School of Medicine, University of California at \\ Los Angeles, Los Angeles, California 90095.
}

\begin{abstract}
The corticostriatal pathway provides most of the excitatory glutamatergic input into the striatum and it plays an important role in the development of the phenotype of Huntington's disease (HD). This review summarizes results obtained from genetic HD mouse models concerning various alterations in this pathway. Evidence indicates that dysfunctions of striatal circuits and cortical neurons that make up the corticostriatal pathway occur during the development of the HD phenotype, well before there is significant neuronal cell loss. Morphological changes in the striatum are probably primed initially by alterations in the intrinsic functional properties of striatal medium-sized spiny neurons. Some of these alterations, including increased sensitivity of N-methyl-D-aspartate receptors in subpopulations of neurons, might be constitutively present but ultimately require abnormalities in the corticostriatal inputs for the phenotype to be expressed. Dysfunctions of the corticostriatal pathway are complex and there are multiple changes as demonstrated by significant age-related transient and more chronic interactions with the disease state. There also is growing evidence for changes in cortical microcircuits that interact to induce dysfunctions of the corticostriatal pathway. The conclusions of this review emphasize, first, the general role of neuronal circuits in the expression of the HD phenotype and, second, that both cortical and striatal circuits must be included in attempts to establish a framework for more rational therapeutic strategies in HD. Finally, as changes in cortical and striatal circuitry are complex and in some cases biphasic, therapeutic interventions should be regionally specific and take into account the temporal progression of the phenotype.
\end{abstract}

\section{Keywords}

Cortex; striatum; electrophysiology; mouse models; glutamate; pathway

\section{Introduction}

\begin{abstract}
Huntington's disease (HD) is a genetic and progressive neurological disorder that is inherited in an autosomal, dominant fashion. The symptoms of HD include abnormal dance-like movements (chorea), cognitive disturbances, and disorders of mood, particularly depression which often precedes the onset of the motor abnormalities (Harper, 1996). The HD gene (IT15) is located on the short arm of chromosome 4 and contains an expansion in the normal number of CAG (glutamine) repeats (generally >40) (Huntington's Disease Collaborative Research Group, 1993). HD is typically a late onset disease although juvenile variants occur, usually when more CAG repeats are present. In young children with HD, the symptoms almost
\end{abstract}

\footnotetext{
Author for Correspondence: Michael S. Levine, Ph.D., Mental Retardation Research Center, Semel Institute for Neuroscience and Human Behavior, Room 58-258, 760 Westwood Plaza, University of California at Los Angeles, Los Angeles, CA 90095 USA, Tel. (310) 825-7595, Fax (310) 206-5060, E-mail: mlevine@mednet.ucla.edu

Publisher's Disclaimer: This is a PDF file of an unedited manuscript that has been accepted for publication. As a service to our customers we are providing this early version of the manuscript. The manuscript will undergo copyediting, typesetting, and review of the resulting proof before it is published in its final citable form. Please note that during the production process errors may be discovered which could affect the content, and all legal disclaimers that apply to the journal pertain.
} 
invariably include epileptic seizures (Gencik et al., 2002;Rasmussen et al., 2000).

Neuropathologically, HD is primarily characterized by neuronal loss in striatum and cortex (for review see Vonsattel and DiFiglia, 1998). In the striatum, medium-sized spiny neurons (MSSNs) are most affected and degeneration of these neurons occurs progressively (Vonsattel et al., 1985). In addition, there is a gradient of striatal pathology progressing in a dorsolateral to ventral direction and another in a caudo-rostral direction (Vonsattel et al., 1985). Although it has been generally believed that the progression of symptoms in the disorder is due to the neurodegeneration, it has become apparent more recently that severe neuronal dysfunction precedes degeneration and is probably the major cause of many symptoms (Levine et al., 2004).

The protein coded by the HD gene (huntingtin) is a large protein $(\sim 350 \mathrm{kDa})$ that is highly conserved and expressed ubiquitously throughout the body (Strong et al., 1993). In the brain, it is predominantly found in neurons (Landwehrmeyer et al., 1995a) and although recent studies have provided important clues, its exact function still remains a mystery (Young, 2003).

However, huntingtin is essential for embryogenesis and normal development, and the loss of normal huntingtin function may contribute to the pathogenesis of HD (reviewed in Cattaneo et al., 2001). Increasing normal huntingtin expression improves neuronal survival and attenuates the effects of the mutant protein (Cattaneo et al., 2005). Huntingtin is a cytoplasmic protein closely associated with vesicle membranes and microtubules, suggesting it may have a role in vesicle trafficking, exocytosis and endocytosis (DiFiglia et al., 1995). In addition, its distribution is very similar to that of synaptophysin (Wood et al., 1996) and it has been shown to associate with various proteins involved in synaptic function. Thus, it is probable that mutant huntingtin causes abnormal synaptic transmission in HD (Li et al., 2003; Smith et al., 2005a).

The mechanism by which mutant huntingtin causes dysfunction and ultimate degeneration of neurons is unknown. One possibility is that proteins with more than 40 glutamine residues precipitate as insoluble fibers (Perutz, 1999), allowing the formation of protein aggregates. Aggregates of mutant huntingtin localize in the nucleus and dystrophic neurites and may be part of the pathogenic mechanisms in HD (DiFiglia et al., 1997). Neuropil aggregates appear to be more common than nuclear aggregates and are more prevalent in cortex than in striatum (Gutekunst et al., 1999). Electron microscopic studies reveal many neuropil aggregates in axon terminals, which are co-localized with synaptic vesicles suggesting they may affect synaptic transmission ( $\mathrm{Li}$ et al., 1999). However, recent evidence has questioned whether these aggregates are the cause of neuronal dysfunction and degeneration. Instead, they could represent a compensatory process to aid in neuronal survival (Slow et al., 2006).

There are several important unresolved questions concerning the progressive neuronal dysfunction in HD. One is, "What is the sequence of events that leads to neuronal dysfunction and ultimate cell death?" Another is, "Why is there selective vulnerability of specific neuronal types within the striatum?" Although the disease affects primarily MSSNs, a puzzling feature of HD is that MSSNs that project to the globus pallidus [these neurons are enkephalin-positive and are the source of the indirect striatal output pathway (Albin et al., 1989)] appear to be affected earlier than those that project to the substantia nigra [these neurons are substance Ppositive and are the source of the direct striatal output pathway (Albin et al., 1989)] (Richfield et al., 1995;Sapp et al., 1995). In other words, MSSNs that originate the indirect pathway are more sensitive to the mutation than cells of the direct pathway.

With regard to the question of the sequence of events that lead to neuronal dysfunction and cell death, there either could be a single event that triggers a cascade of cellular alterations, similar to a chain reaction, or independent alterations may occur simultaneously or progressively in different neuronal systems. The idea that the initial and principal instigators of striatal dysfunction are not intrinsic to the striatum is not new. There is considerable evidence 
that the earliest manifestations of HD are the emotional and cognitive disturbances. It is thus possible that areas related to these early alterations, such as the limbic system, the cerebral cortex or even the hypothalamus (Petersén et al., 2005) are the initial triggers of changes in motor functions ultimately mediated via the striatum. In fact, it has been speculated that cortical changes are fundamental to the onset and progression of the HD phenotype in humans and in mouse models (Laforet et al., 2001).

Because the key neuronal structures that display dysfunction and ultimate degeneration in HD are interconnected via long circuit loops (corticostriatal connections, striatal outputs to globus pallidus and substantia nigra, substantia nigra and globus pallidus projections to thalamus and thalamic projections back to the cortex), there are many synaptic interactions that can contribute to the functional alterations observed in HD. Ever since the pioneering studies by Wong et al. (1982) demonstrating perturbations in the synthesis of glutamate by corticostriatal neurons in $\mathrm{HD}$, investigations of this pathway have been at the core of multiple attempts to understand the mechanisms of HD pathology. The remainder of this review primarily will concentrate on the electrophysiological changes that have been observed in MSSNs, cortical neurons, and in the corticostriatal pathway. We will also concentrate on findings obtained from genetic mouse models as they represent the best approach at the present time to unraveling the sequence of changes and determining why certain types of neurons may be more affected by the HD mutation.

\section{Genetic mouse models of HD}

The generation of genetic mouse models of HD has helped to understand the dysfunctions underlying behavioral phenotypes, neuronal abnormalities and neurodegeneration. A great advantage of these models, compared to the more classic excitotoxic models of HD, is that they allow examination of the evolution of the disease and the discovery of cause-effect relationships. Because a detailed description of these models is not the primary objective of the present article, we remit the reader to consult other recent reviews (Brouillet et al., 1999;Bates and Murphy, 2002;Hickey and Chesselet, 2003;Levine et al., 2004;Menalled and Chesselet, 2002;Rubinsztein, 2002).

At present, a number of transgenic, knock-in, and conditional mouse models have been developed and the electrophysiological and morphological cellular alterations have been extensively examined. We have primarily utilized transgenic animal models, including the R6/1 and R6/2 (Mangiarini et al., 1996), YAC72 and 128 (Hodgson et al., 1999;Slow et al., 2003), the Tg100 (Laforet et al., 2001), as well as several knock-in models, CAG71 and CAG94 (Levine et al., 1999).

One of the most studied models is the R6 line of transgenic mice (Mangiarini et al., 1996). In particular, R6/2 mice, with $\sim 150 \mathrm{CAG}$ repeats, manifest a very aggressive form of HD, somewhat similar to the juvenile variant. Transgenic animals display overt behavioral symptoms as early as $4-5$ weeks of age and die of unknown causes at about 15 weeks. Affected animals display a number of alterations including the formation of neuronal intranuclear inclusions (Davies et al., 1997), changes in neurotransmitter receptor expression (Ariano et al., 2002; Cha et al., 1998), and altered signaling mechanisms (Bibb et al., 2000; Luthi-Carter et al., 2000;Menalled et al., 2000). There are also metabolic deficits in transgenic animals (Higgins et al., 1999; Tabrizi et al., 2000). These alterations are correlated with characteristic motor (Carter et al., 1999) and learning deficits (Lione et al., 1999;Murphy et al., 2000). R6/1 mice display a similar phenotype, but in a much more protracted form. Another model, Tg100, expresses the $\mathrm{N}$-terminal one-third of huntingtin with normal (18) or expanded (100) glutamine repeats. These transgenic mice exhibit motor deficits beginning at 3 months and progress with 
increasing age. Nuclear inclusions precede the onset of the phenotype, whereas pathological cortical changes predict the onset and severity of behavioral deficits (Laforet et al., 2001).

Other widely used transgenic mice were generated using yeast artificial chromosomes (YAC) expressing normal (YAC18) and mutant (YAC46 and YAC72) huntingtin (Hodgson et al., 1999). These mice show behavioral changes around 7 months of age, as well as selective degeneration of MSSNs in the lateral striatum by 12 months of age. Neurodegeneration can be present in the absence of aggregates in YAC mice, showing that they are not essential to initiation of neuronal death (Hodgson et al., 1999). YAC128 mice display similar but more severe alterations which occur earlier than in YAC72 mice (Slow et al., 2003).

Knock-in models have also emerged as a major contributor to our understanding of HD. Several models that differ mainly in the number of CAG repeats (from 48 to 150) have been generated (Levine et al., 1999;Lin et al., 2001; Shelbourne, et al., 1999; Wheeler et al., 2000; White et al., 1997). Although in knock-in mice overt behavioral changes are subtle, more sensitive and careful testing demonstrated behavioral abnormalities as early as 1-2 months of age (Menalled et al., 2002;2003). Further, a consistent feature in several models of knock-in mice is the presence of nuclear staining and microaggregates at 2-6 months, which is relatively early in the course of the disease. By contrast, nuclear inclusions are only observed when the mice are older (10-18 months, depending on the model), and extensive cell death has not yet been reported (Menalled and Chesselet, 2002).

Conditional mouse models of HD have also been generated. One model expresses exon 1 with 94 CAG repeats in a tetracycline-regulated manner (Yamamoto et al., 2000). These mice develop progressive motor decline and striatal atrophy in the absence of striatal neuronal loss up to 10 months of age, although cell loss occurs in older mice (Diaz-Hernandez et al., 2005). Abolishing transgene expression in symptomatic mice leads to the disappearance of inclusions and amelioration of the behavioral phenotype, even in mice presenting with striatal cell loss (Diaz-Hernandez et al., 2005; Yamamoto et al., 2000). More recently, Cre/LoxP conditional HD mice expressing mutant huntingtin with 103 glutamine repeats, either in all neurons of the brain or restricted to the vulnerable cortical pyramidal neurons, have been generated (Gu et al., 2005). Interestingly, in these models huntingtin aggregation was shown to be a cellautonomous process, whereas motor deficits and cortical neuropathology were observed only when mutant huntingtin expression occurred in multiple neuronal types, including cortical interneurons, but not when it was restricted to cortical pyramidal neurons (Gu et al., 2005).

\section{The corticostriatal pathway and its target neurons in the striatum}

\subsection{Cell types in the striatum and their vulnerability in HD}

The striatum is the main input compartment of the basal ganglia. It receives massive glutamatergic and dopaminergic innervations. The excitatory glutamatergic input derives mainly from all regions of the cerebral cortex as well as specific thalamic nuclei (Fonnum et al., 1981; Jones, 1987). The dopaminergic input comes from the pars compacta of the substantia nigra (Carlsson et al., 1962). These inputs interact on MSSNs (Smith and Bolam, 1990). The mode of interaction between dopamine and glutamate has been an area of controversy, but it is generally believed that dopaminergic inputs modify the excitatory responses induced by glutamate (Cepeda and Levine, 1998;2006).

The ubiquitous MSSNs, comprising more than $90 \%$ of the striatal cell population, are projection neurons (Kemp and Powell, 1971) and, although all MSSNs are GABAergic, they differ in a number of properties including the expression of dopamine and acetylcholine receptor subtypes, peptide content, and their projection targets (Gerfen, 1992). Two major neuronal subpopulations of MSSNs have been described, the direct pathway that projects to 
the substantia nigra pars reticulata and the internal segment of the globus pallidus (entopeduncular nucleus in rodents), and the indirect pathway that projects to the external segment of the globus pallidus (Smith et al., 1998). MSSNs at the origin of the direct pathway mainly express dopamine D1 and muscarinic M4 receptors, and colocalize substance P, whereas MSSNs of the indirect pathway mainly express dopamine D2 receptors and colocalize enkephalin, although some overlap exists (Aizman et al., 2000;Surmeier et al., 1996). Recent evidence supports differential cortical innervation of these subpopulations of MSSNs (Lei et al., 2004) which may be important in the development of symptoms in HD as the enkephalincontaining neurons of this pathway seem to be affected earlier (Richfield et al., 1995;Sapp et al., 1995).

In addition to MSSNs there are multiple classes of interneurons in the striatum. At least four classes of interneurons have been recognized: cholinergic, fast-spiking GABAergic, nitric oxide synthase-positive and calretinin-positive interneurons (Kawaguchi et al., 1995). Fast spiking interneurons receive direct inputs from the cerebral cortex and synapse onto MSSNs (Bennett and Bolam, 1994;Plotkin et al., 2005). Interneurons appear to be less affected in HD than projection MSSNs. Unfortunately, striatal interneurons have not been extensively studied as yet in mouse models. However, even though striatal interneurons are spared in the disease, they also could become dysfunctional and play a role in the HD phenotype (Picconi et al., 2006). For example, immunohistochemical evidence in humans indicates that the number of medium-sized calretinin-positive interneurons is selectively increased in HD (Cicchetti and Parent, 1996).

\subsection{The gatekeepers of glutamate release in the corticostriatal pathway}

Striatal cells, particularly the MSSNs and to a lesser extent interneurons, are constantly bombarded by excitatory cortical inputs. In fact, MSSNs remain hyperpolarized and silent (down state), unless synchronous cortical inputs induce a membrane depolarization (up state) (Wilson and Kawaguchi, 1996). Continuous exposure to glutamate inputs could make MSSNs particularly vulnerable to excitotoxic damage. For example, depolarization is critical for removal of the $\mathrm{Mg}^{2+}$ block of NMDA receptor-channels, which when open are generally believed to induce excitotoxicity. However, intrinsic conductances and presynaptic regulation of glutamate inputs can contribute to prevent excessive activation of MSSNs. First, inwardly rectifying $\mathrm{K}^{+}$conductances keep the membrane hyperpolarized and reduce input resistance and time constant, thereby effectively limiting the efficacy of glutamatergic synaptic inputs (Nisenbaum and Wilson, 1995). Second, a number of receptors strategically placed on the corticostriatal terminals exert presynaptic regulation of glutamate release. These include dopamine $\mathrm{D} 2$, group II metabotropic glutamate $\left(\mathrm{mGluR}_{2}\right.$ and $\left.\mathrm{mGluR}_{3}\right), \mathrm{GABA}_{\mathrm{B}}$, cannabinoid $\left(\mathrm{CB}_{1}\right)$ and adenosine $\left(\mathrm{A}_{1}\right)$ receptors (Calabresi et al., 1990;Cepeda et al., 2001b;FloresHernandez et al., 1997;Gerdeman and Lovinger, 2001;Hsu et al., 1995;Huang et al., 2001;Lovinger and Choi, 1995;Lovinger and McCool, 1995;Lovinger et al., 1993;Malenka and Kocsis, 1988;Nisenbaum et al., 1992). Alterations in the expression or function of these receptors could contribute to the dysfunction in $\mathrm{HD}$, as unregulated release of glutamate would jeopardize the integrity of MSSNs, the main recipients of cortical inputs. In fact, the earliest behavioral manifestations of $\mathrm{HD}$ in mice coincide with reduced expression of striatal dopamine D2, mGlu and $\mathrm{CB}_{1}$ receptors (Ariano et al., 2002;Cha, et al., 1998;Luthi-Carter et al., 2000). The mechanisms underlying receptor regulation of glutamate release are complex and in some cases controversial. Regardless of the mechanisms of presynaptic modulation of glutamate release, what is relevant in the present context is that functional alterations in cortical pyramidal neurons or in the receptor expression on presynaptic endings of the corticostriatal pathway, the gatekeepers of striatal excitation, could play an important role in HD neuropathology. The major issue then becomes what are the potential consequences of dysregulation of glutamate release along the corticostriatal pathway in HD? 


\section{Electrophysiology and morphology of the striatum and cortex in mouse models of HD}

\subsection{Morphology in striatum and cortex}

Electrophysiological alterations in the corticostriatal pathway are likely to produce morphological changes in postsynaptic neurons as a consequence of dysregulation of glutamate release. Neuronal death is not prominent in most HD mouse models, although it does occur. It is a late event that seems dependent on which transgenic or knock-in model is examined. In the R6 line neuronal loss is modest and occurs very late in the life of the animal (Turmaine et al., 2000). However, we have observed early and significant changes in striatal somatodendritic morphology that would indicate dysfunctional neurons and synaptic connections (Klapstein et al., 2001;Levine et al., 1999). Somatic areas and dendritic fields are reduced. Recurving dendrites are apparent in striatal neurons, similar to those found in HD patients (Graveland et al., 1985). Loss of spines may be an early morphological change. Alterations in cortical pyramidal neurons also occur (Klapstein et al., 2001;Laforet et al., 2001). In symptomatic R6/1 mice there is a decrease in dendritic spine density and dendritic spine length in striatal MSSNs and cortical pyramidal neurons (Spires et al., 2004). HD also causes a specific reduction in the proportion of bifurcated dendritic spines on basal dendrites of cortical pyramidal neurons. Decreases in the number of dendritic spines on MSSNs will disrupt corticostriatal networks and spine decreases on cortical pyramidal neurons will lead to cortical information processing abnormalities. In contrast to the R6 line, the YAC72 and YAC128 models display selective degeneration of MSSNs in the lateral striatum after several months of age (Hodgson et al., 1999; Slow et al., 2003). In another full-length transgenic mouse model with 48 or 89 CAG repeats, a decrease in the number of dendritic spines occurred without significant cell loss (Guidetti et al., 2001).

Other cortical changes also are apparent. There is clear evidence for a progressive thinning of the cortical ribbon and pyramidal neuron loss in HD patients (Cudkowicz and Kowall, 1990;de la Monte et al., 1988;Halliday et al., 1998;Hedreen et al., 1991;MacDonald and Halliday, 2002;Rosas et al., 2002; Sotrel et al., 1991). Early degeneration of the corticostriatal pathway may occur in conjunction with the accumulation of mutant huntingtin in axonal swellings in striatal neuropil and in the cytoplasm of cortical neurons (MacDonald and Halliday, 2002; Sapp et al., 1999). These changes in cortical projection neurons may lead to alterations in synaptic function and receptor responsiveness. For example, huntingtin alters axonal transport and the mutated form disrupts neurotransmitter release which will affect neuronal circuitry (Li et al., 1998;Li et al., 2003).

The alterations in cortical pyramidal neurons may not be primary nor sufficient to cause the HD phenotype. The question then becomes, which mechanism can better explain HD neuropathology? Is neuronal dysfunction and degeneration caused by cell-autonomous toxicity of mutant huntingtin (cell-autonomy model) or by altered cellular interactions (cell-cell interation model)? As exemplified in a conditional model of HD, neuropathology in different areas seems to occur only when mutant huntingtin is widely expressed in the brain, supporting the cell-cell interaction, not the cell-autonomy, model for cortical and striatal pathogenesis (Gu et al., 2005).

\subsection{Electrophysiology in cortex}

In the same conditional model electrophysiological studies showed a reduction of GABAergic inhibitory input onto cortical pyramidal cells only in mice expressing mutant huntingtin widely in the brain, but not when it was restricted to the cortical pyramidal neurons alone (Gu et al., 2005). This is significant because some models of HD display spontaneous epileptic seizures and/or have a reduced epileptic threshold after systemic injection of $\mathrm{GABA}_{\mathrm{A}}$ receptor 
antagonists bicuculline or picrotoxin (Cummings et al., 2006b;Uzgil et al., 2004). This implies that cortical hyperexcitability due to impaired inhibition could be an early event in HD. Other types of cortical abnormalities occur in R6/2 mice and these may underlie changes in information processing. We have shown that currents induced by glutamate receptor agonists are decreased in isolated cortical pyramidal neurons from R6/2 mice, possibly contributing to changes in cortical integration and output that underlie the cognitive and motor impairments in this animal model of HD (André et al., 2006). Interestingly, high voltage-activated (HVA) $\mathrm{Ca}^{2+}$ currents in cortical pyramidal neurons are increased in symptomatic mice, suggesting complex changes that may effectively increase excitability altering corticostriatal function (André et al., 2006; Cherry et al., 2002). Electrophysiological alterations also occur in the striatum and at similar time points. Thus, we do not know if changes occur first in cortex or striatum or if they occur simultaneously.

\subsection{Passive and active cellular membrane properties in striatum}

One of the earliest and most consistent alterations in the basic membrane properties of MSSNs in the R6/2 transgenic mouse model is an increase in input resistance. This increase probably reflects loss of conductive membrane channels due to morphological changes such as reduced membrane area possibly as a consequence of the loss of spines. Consistent with this observation, cell capacitance is significantly reduced in symptomatic animals (Cepeda et al., 2001a;Klapstein et al., 2001;Levine et al., 1999). The increase in membrane input resistance could also be due to alterations in the number and/or properties of $\mathrm{K}^{+}$channels. This possibility is supported by gene expression studies showing decreases in inwardly rectifying $\mathrm{K}^{+}$channels and the $\beta 1$ subunit of the $\mathrm{K}^{+}$channel (Luthi-Carter et al., 2000). Furthermore, in R6/2 and $\operatorname{Tg} 100$ transgenic mice, membrane expression of proteins responsible for inwardly and outwardly rectifying $\mathrm{K}^{+}$currents is diminished in striatal projection neurons (Kir2.1 and Kir2.3 for inward and Kv2.1 for outward rectification) (Ariano et al., 2005a,b). As a consequence, many MSSNs have a depolarized resting membrane potential (Klapstein et al., 2001;Levine et al., 1999) and are less able to repolarize (Ariano et al., 2005a). These alterations are particularly relevant because membrane depolarization can remove the $\mathrm{Mg}^{2+}$ block of the NMDA receptor causing neurons to become more depolarized when glutamatergic inputs are activated and they will stay in a depolarized state for longer periods of time.

Other voltage-gated conductances may also be affected as alterations in firing patterns occur in some striatal cells from symptomatic R6/2 mice (Klapstein et al., 2001). For example, there is a reduction in HVA $\mathrm{Ca}^{2+}$ conductances (Bibb et al., 2000;Cepeda et al., 2001a;Starling et al., 2005). This effect appears to occur after 7 weeks of age in the R6/2 transgenics, and is also likely to affect the firing patterns of MSSNs. In recent preliminary experiments we have also observed an increase in voltage-gated $\mathrm{Ca}^{2+}$ conductances in MSSNs from younger (3-6 weeks of age) R6/2 mice (Plotkin and Levine, 2006;Starling et al., 2005). This, in conjunction with other changes in membrane properties, could explain increased spontaneous firing rates in some striatal neurons from R6/2 mice at 6-9 weeks of age, an effect that is reversed by repeated ascorbate treatment (Rebec et al., 2006). Therefore, the changes in $\mathrm{Ca}^{2+}$ conductances may be biphasic and region specific. This could mean that the effects of mutant huntingtin on some voltage-gated currents in MSSNs are not unidirectional and can change over time, either as a consequence of the natural evolution of the disease or as a compensatory mechanism.

Taken together the complex set of alterations in voltage-gated conductances of MSSNs will produce dysfunctional cells that have altered responses to inputs. Early increases in $\mathrm{Ca}^{2+}$ conductances will predispose cells to more easily become depolarized while subsequent decreases might be protective. Early increases in input resistance will decrease electrotonic decay of conductances allowing peripheral inputs to depolarize over longer distances while specific changes in $\mathrm{K}^{+}$channel function can also predispose neurons to remain depolarized 
and more excitable. In particular, decreased inward rectification could amplify excitatory inputs. These postsynaptic changes in voltage-gated currents stress the level of complexity of events when trying to determine if striatal neuron pathology is a primary effect or the consequence of alterations in other brain regions. They also emphasize that striatal MSSNs are dysfunctional and may be primed to be affected by abnormal cortical inputs.

\subsection{Glutamate receptors}

The main hypothesis underlying striatal neurodegeneration in HD has been excitotoxicity (DiFiglia, 1990). This hypothesis emanated from many studies demonstrating parallels in the effects of excitotoxic or chemical lesions of the striatum with those observed in HD in patients. In general, excitoxicty can result from a number of changes, either together or in isolation. These include an increase in release of excitatory neurotransmitters like glutamate, and an increase in responsiveness of glutamate receptors either due to an increase in receptor density or number or a change in receptor composition or their signaling properties. Since NMDA receptors are intimately associated with excitoxicity, they were one of the first glutamate receptors studied in mouse models of HD.

In all models of HD examined thus far we and others have found that many MSSNs are more sensitive to exogenous application of NMDA. We first examined NMDA-induced cell swelling in the R6/2 and two knock-in mouse models of HD, CAG71 and CAG94 (Levine et al., 1999). There was an overall increase in cell swelling in transgenic and CAG94 mice compared to controls indicating cells from these HD models are more sensitive to NMDA. Interestingly, the increase in sensitivity was limited to NMDA receptors, as sensitivity to kainate was not affected. Electrophysiological and $\mathrm{Ca}^{2+}$ imaging studies supported these observations (Cepeda et al., 2001a). A subpopulation of cells from transgenic animals (R6/2, YAC72 and Tg100) displayed larger NMDA currents and NMDA-induced $\mathrm{Ca}^{2+}$ influx than cells from littermate controls, whereas the remainder of cells displayed normal responses (Cepeda et al., 2001a;Laforet et al., 2001). The more sensitive cells could correspond to the enkephalincontaining MSSNs that are more affected in HD. Similar increases in NMDA receptor sensitivity have been observed in the YAC72 model (Zeron et al., 2002). Interestingly, acute treatment with succinate dehydrogenase inhibitors (e.g., 3-nitropropionic acid, 3-NP) augments NMDA receptor-mediated corticostriatal excitation in striatal MSSNs (Centonze et al., 2001).

Cells from transgenic animals also displayed reduced NMDA receptor $\mathrm{Mg}^{2+}$ sensitivity (Cepeda et al., 2001a). Changes in $\mathrm{Mg}^{2+}$ sensitivity occur very early in R6/2 mice. In dissociated striatal neurons a group of cells from transgenic mice displayed increased responses to NMDA and decreased $\mathrm{Mg}^{2+}$ sensitivity as early as 15 days of age, suggesting the presence of constitutively abnormal NMDA receptors (Starling et al., 2005). Early changes in NMDA receptor sensitivity were also found in the YAC72 mouse model, supporting the presence of constitutively abnormal NMDA receptors (Zeron et al., 2002). Further, increased sensitivity was specific for this type of receptor as the sensitivity of $\alpha$-amino-3-hydroxy-5-methyl-4isoxazolepropionic acid (AMPA) receptors was unchanged (Zeron et al., 2002). This agrees with the observation that cell swelling is not differentially affected by non-NMDA receptor activation in control and symptomatic HD mice (Levine et al., 1999). However, in a more detailed study on the evolution of changes in postsynaptic sensitivity of AMPA receptors in dissociated MSSNs from R6/2 mice, we have shown a delayed developmental reduction in AMPA current amplitude. Whereas in control mice AMPA current amplitude decreases from 21 to 40 days, in transgenic animals AMPA current amplitude remains high and does not decrease until later, during the symptomatic stage, when the amplitude becomes similar in transgenic and control mice (Joshi et al., 2006). These results suggest that abnormal AMPA 
receptor function in striatal MSSNs occurs in pre-symptomatic and early symptomatic phases in the R6/2 mouse model.

The mechanism that causes increases in NMDA receptor sensitivity in HD remains unknown. One explanation is that huntingtin with expanded polyQ tracts interferes with the binding of PSD95, a scaffolding protein found at the postsynaptic density, to the NR2 NMDA and GluR6 kainate receptor subunits, causing both receptors to become hypersensitive to glutamate (Sun et al., 2001). Another possible explanation is that there is a change in the subunit composition of NMDA receptors. Increased responsiveness to NMDA correlates with an increase of NR1 subunit protein expression and reduced NR2A/B protein expression (Ariano et al., 2005b;Cepeda et al., 2001a). We used single cell RT-PCR to demonstrate further that in the $\mathrm{R} 6 / 2$ transgenic there was an early decrease in the number of MSSNs expressing mRNA for the NR2A receptor subunit (Ali and Levine, 2006), providing evidence that different types of NMDA receptors are expressed in mutant mice. This decrease in NR2A expression would thus cause NMDA receptors to express the NR2B subunit more exclusively. A similar conclusion has been reached for the YAC72 and YAC128 mouse models of HD (Li et al., 2003;

2004; Shehadeh et al., 2006).

\subsection{Synaptic responses}

Mutant huntingtin has been shown to impair directly the cellular machinery involved in synaptic transmission. Proteins involved in the control of neurotransmitter release such as complexin II, synaptobrevin and synapsin I are affected early (Liévens et al., 2002; Morton and Edwardson, 2001; Morton et al., 2001). Rabphilin 3A, another protein involved in exocytosis, is also substantially decreased in synapses of most brain regions in $\mathrm{R} 6 / 1$ mice. This reduction coincides with the onset of behavioral deficits and may be the cause of impaired synaptic transmission in these mice (Smith et al., 2005). Recent studies have demonstrated an important role for huntingtin and its $\mathrm{N}$-terminal fragments in the uncoupling of syntaxin $1 \mathrm{~A}$ (another protein that plays an essential role in synaptic transmission) with the $\mathrm{N}$-type $\mathrm{Ca}^{2+}$ channel (Swayne et al., 2005). Huntingtin and its fragments influence synaptic transmission by enhancing $\mathrm{Ca}^{2+}$ influx and uncoupling the exocytotic machinery from the $\mathrm{N}$-type $\mathrm{Ca}^{2+}$ channel (Swayne et al., 2005). Alterations in cross-talk between these two essential proteins have the potential of playing a crucial role in synaptic perturbations in HD.

In the corticostriatal pathway, cellular pathology caused by mutant huntingtin in the presynaptic terminals might result in an increased release of glutamate. Alternatively, impaired clearance of glutamate from the synaptic cleft might increase glutamatergic neurotransmission. In both cases, striatal excitotoxicity could occur (Beal et al., 1986;Zeron et al., 2002).

Intracerebral microdialysis has shown that depolarizing concentrations of potassium chloride increase the extracellular concentrations of glutamate substantially more in R6/1 mice than in wildtype mice (NicNiocaill et al., 2001). In addition, the glial glutamate transporter (GLT-1) is downregulated in R6/2 mice before any evidence of neurodegeneration (Liévens et al., 2001). This indicates that there is an impairment in glutamate transport and glutamateglutamine cycling, and suggests that a defect in astrocytic glutamate uptake could contribute to the phenotype and to neuronal cell dysfunction in HD. Finally, mutant huntingtin binds to synaptic vesicles with a higher affinity than does the wildtype form and inhibits the uptake of glutamate into synaptic vesicles in a dose-dependent manner (Li et al., 2000). These alterations combined could lead to increased glutamate in and around the synaptic cleft.

4.5.1 Evoked synaptic responses-One of the first indications of electrophysiological changes in the corticostriatal pathway was the observation that the stimulus intensity necessary to evoke an excitatory postsynaptic potential (EPSP) in MSSNs was significantly increased in symptomatic R6/2 and Tg100 transgenic mice (Klapstein et al., 2001;Laforet et al., 2001). A 
similar trend occurred in YAC72 mice, although the effect was much smaller. Another important observation was that symptomatic R6/2 transgenics displayed slower rise and incomplete decay of the EPSP. This phenomenon was hypothesized to indicate a larger contribution of a slower kinetic current, such as the one mediated by activation of NMDA receptors. This idea is supported by the observation of enhanced NMDA responses associated with increased NR1 subunit expression (Levine et al. 1999;Cepeda et al. 2001a). In addition, synaptic responses mediated by activation of NMDA receptors are enhanced in R6/2 mice at 40 days of age, when overt symptoms are just beginning to occur (Wu et al., 2004).

In other mouse models similar and specific enhancement of synaptic responses mediated by activation of NMDA receptors has been found. For example, in YAC72 mice a larger NMDA to AMPA receptor-mediated current ratio occurs ( $\mathrm{Li}$ et al., 2003) and may be caused by increased surface expression of NMDA receptors containing the NR2B subunit (Li et al., 2004). Recently, we recorded evoked synaptic responses in MSSNs from YAC128 mice. These mice are similar to the YAC72 model but the phenotypic changes occur earlier and are more dramatic (Slow et al., 2003). Interestingly, the synaptic alterations were age-dependent. At 40 days mean peak AMPA and NMDA receptor-mediated current amplitudes were significantly increased in YAC128 compared to wildtype mice. In contrast, at 7 months, mean peak amplitudes of AMPA and NMDA responses were smaller in YAC128 than in wildtype mice (Levine et al., 2005). These findings are consistent with the biphasic motor phenotype observed in YAC128 mice, hyperactivity followed by hypoactivity. These results emphasize that synaptic alterations in some HD mouse models are not static but change with disease progression and that different models may display contrasting alterations in synaptic responses.

4.5.2 Spontaneous excitatory postsynaptic currents-In addition to alterations in evoked synaptic responses, we demonstrated both transient and progressive changes in spontaneous synaptic currents in transgenic R6/2 mice (Cepeda et al., 2003). Spontaneous excitatory postsynaptic currents showed a progressive reduction in frequency that became more evident as the neurological phenotype advanced. We interpreted these effects as a progressive disconnection between the striatum and its cortical inputs. Reduced glutamatergic synaptic currents were correlated with a marked reduction in the expression of synaptic marker proteins synaptophysin and PSD95 (Cepeda et al., 2003). This could be associated with the loss of dendritic spines.

In R6/2 animals there was also a transient expression of complex, large amplitude ( $>100 \mathrm{pA})$ synaptic currents at 5-7 weeks of age that coincided with the onset of behavioral symptoms (Cepeda et al., 2003). We hypothesized that these large currents reflect dysregulation of glutamate release and/or an increase in cortical synchronization. Dysregulation of glutamate release can also be contributed by increased $\mathrm{HVA} \mathrm{Ca}^{2+}$ currents in cortical pyramidal neurons (André et al., 2006; Cherry et al., 2002). The fact that R6 mice often develop epileptic seizures implies that the cortex in these HD mice becomes hyperexcitable. Interestingly, synchronous cortical input, similar to that produced by local application of picrotoxin in the cortex, appears to target enkephalin-positive neurons preferentially (Berretta et al., 1997). These neurons are more vulnerable in HD (Mitchell et al., 1999;Richfield et al., 1995;Sapp et al., 1995) and enkephalin expression seems to depend on intact cortical inputs (Uhl et al., 1988). In addition, alterations in the function or density of presynaptic D2, mGluR, endocannabinoid, and adenosine receptors regulating glutamate release could contribute to the occurrence of large synaptic events (Ariano et al 2002; Cha et al., 1998). Finally, postsynaptic AMPA receptor dysfunction in R6/2 mice (Joshi et al., 2006), in conjunction with transient increases in HVA $\mathrm{Ca}^{2+}$ currents in MSSNs (Plotkin and Levine, 2006; Starling et al., 2005), could also favor the occurrence of large synaptic events. 
Our hypothesis that, concomitant to the transient dysregulation of glutamate release, there is a progressive disconnection between cortex and striatum in R6/2 transgenics has important implications. First, it casts doubts on the belief that chronic excess glutamate release is the sole mechanism underlying striatal cell death. Indeed, release studies have been inconclusive. Either no change or a reduction of glutamate in the striatum has been observed (Behrens et al., 2002;Liévens et al., 2001;NicNiocaill et al., 2001). Second, the progressive disconnection between MSSNs and their cortical inputs may deprive these cells of important trophic factors necessary for normal function such as brain derived neurotrophic factor [BDNF (Zuccato et al., 2001)].

This progressive disconnection could help explain the surprising and seemingly paradoxical observation that, in some mouse models of $\mathrm{HD}$, striatal lesions produced by injections of quinolinic acid or kainate are dramatically reduced compared to control animals (Hansson et al., 1999; Morton and Leavens, 2000). Reduced receptor sensitivity to these excitatory amino acid receptor agonists can be ruled out because immediate early gene responses do not appear impaired, suggesting that resistance may be conferred by other processes further along the toxic cascade (MacGibbon et al., 2002). We have proposed that the progressive loss of cortical inputs explains neuroprotection at least in R6/2 mice. It has long been recognized that in order to produce an excitotoxic lesion in the striatum the integrity of the excitatory cortical projection is required (Bizière and Coyle, 1979;McGeer et al., 1978;Orlando et al., 2001). The integrity of this projection is severely compromised in R6/2 mice, which then contributes to the neuroprotection. This hypothesis is supported by the observation that young transgenic animals and other mouse models are not protected against excitotoxic lesions (Petersén et al., 2002), indicating that the HD mutation per se is not neuroprotective. Because neuroprotection develops against various insults such as cerebral ischemia (Schiefer et al., 2002a), 3-NP (Hickey and Morton, 2000), dopamine-induced toxicity (Petersén et al., 2001) and methamphetamine (MacGibbon et al., 2002), it is likely that other factors may also be involved. Alternatively, the progressive development of neuroprotection may reflect compensatory mechanisms. In a recent study, we showed that striatal field potentials of 3-4 week R6/2 transgenic mice show significantly more sensitivity to ischemic challenge than do their WT counterparts. However, the R6/2 responses do not become more sensitive over age but rather maintain a relative tolerance to ischemia compared to controls (Klapstein and Levine, 2005). Metabolic deficiencies could explain increased sensitivity to ischemia in presymptomatic mice, but compensatory mechanisms may take place in striatal neurons to induce ischemic tolerance.

\subsection{GABA function in HD}

Glutamate release can be regulated by $\mathrm{GABA}_{\mathrm{B}}$ receptors located on corticostriatal terminals (Charara et al., 2000;Lacey et al., 2005). Activation of these receptors exerts significant inhibitory effects (Calabresi et al., 1990;Nisenbaum et al., 1992). In contrast to the progressive down-regulation of glutamate synaptic transmission, GABAergic function was unexpectedly increased in symptomatic R6 mice. These effects were manifested by increased frequency of spontaneous GABAergic synaptic currents, increased responses to exogenous GABA application, and increased expression of the $\mathrm{GABA}_{\mathrm{A}}$ receptor $\alpha 1$ subunit (Centonze et al., 2005; Cepeda et al., 2004a). Changes in GABAergic synaptic currents occur relatively early in R6/2 mice (5-7 weeks), concurrent with the first overt behavioral manifestations of the disease, and are also observed in R6/1 mice which display a much slower disease progression.

The onset of increased GABA synaptic activity in R6/2 mice coincides with the presence of large synaptic events in a subpopulation of MSSNs. This phasic glutamatergic surge may induce postsynaptic changes that cause increased GABAergic input into MSSNs and corticostriatal terminals. It is tempting to speculate that this increase represents a compensatory mechanism to reduce the potentially deleterious effects of glutamate increases. This 
mechanism would reduce glutamate release via activation of $\mathrm{GABA}_{\mathrm{B}}$ receptors on presynaptic terminals, and by shunting the effects of excitatory inputs via activation of $\mathrm{GABA}_{\mathrm{A}}$ receptors on MSSNs.

Changes in $\mathrm{GABA}_{\mathrm{A}}$ receptor function may contribute to symptoms in HD. In particular, increased inhibition of enkephalin-positive GABAergic neurons would reduce striatal output along the indirect pathway, similar to a functional ablation. This may lead to disinhibition of the external globus pallidus and could explain why lesions in this area ameliorate some HD symptoms (Ayalon et al., 2004;Reiner, 2004).

\section{Synaptic Plasticity in HD}

Alterations in synaptic plasticity in genetic mouse models of HD were first conducted in the hippocampus. The rationale was twofold: first, because cognitive changes precede motor alterations and second, because the hippocampus shows early neuronal intranuclear inclusions (Morton et al., 2000). A number of studies concluded that hippocampal long-term potentiation (LTP) is altered in HD mouse models (Hodgson et al., 1999;Murphy et al., 2000;Usdin et al., 1999). In R6/2 mice alterations in synaptic plasticity occur at both CA1 and dentate granule cell synapses, and are accompanied by impaired spatial cognitive performance. Further, deficits in synaptic plasticity at CA1 synapses occurred before an overt phenotype suggesting that altered synaptic plasticity contributes to the presymptomatic changes in cognitive function reported in human HD (Murphy et al., 2000). In R6/1 mice aberrant long-term depression (LTD) in the hippocampus has also been observed. LTD is developmentally regulated, dependent on NMDA receptors, and normally declines by early adulthood. Young R6/1 mice follow the same pattern of hippocampal LTD expression as controls, but later regain the ability to support LTD (Milnerwood et al., 2006). Mossy fiber LTP in the CA3 region of the hippocampus is also severely impaired in slices from R6/2 mice (Gibson et al., 2005). Interestingly, a similar impairment is observed in mice lacking complexin II, a presynaptic protein that modulates neurotransmitter release and that is depleted in the brains of HD patients and R6/2 mice (Morton and Edwardson, 2001).

Synaptic plasticity is also altered in the cortex of R6/1 mice. Thus, a progressive derailment of LTD at perirhinal synapses is observed in association with early nuclear localization of mutant huntingtin in layers II/III (Cummings et al., 2006a). Interestingly, similar to the changes in membrane properties observed in striatal MSSNs, cortical pyramidal neurons display depolarization and reduced capacitance. More importantly, reduced expression of dopamine receptors occurs in the perirhinal cortex and application of a dopamine D2 agonist can reverse abnormal synaptic plasticity (Cummings et al., 2006a).

It is a natural consequence that cellular and synaptic alterations in MSSNs should affect synaptic plasticity in the striatum. Striatal synaptic plasticity is complicated and remains controversial. Although it was initially believed that LTD was the physiological form of synaptic plasticity after high-frequency stimulation of the corticostriatal pathway, a growing number of studies have demonstrated that this is not the case and that, in fact, both LTD and LTP can be induced in physiological conditions (Charpier and Deniau, 1997; Dos Santos Villar and Walsh, 1999;Mahon et al., 2004;Smith et al., 2001;Spencer and Murphy, 2000). Furthermore, in a corticostriatal slice preparation that better preserves cortical inputs, highfrequency stimulation consistently induced LTP, whereas low-frequency stimulation reliably induced LTD (Fino et al., 2005).

Little is known about changes in striatal synaptic plasticity in HD models. In a recent study, synaptic plasticity in dorsolateral striatal slices from control and 3-NP-treated rats demonstrated that both forms of activity-dependent synaptic plasticity can be recorded in control rats, whereas in 3-NP slices a suppression of LTD expression occurred (Dalbem et al., 
2005). This is consistent with the observation that acute application of 3-NP in striatal slices produced a LTP of the NMDA receptor-mediated synaptic excitation in striatal MSSNs but not in cholinergic interneurons (Calabresi et al., 2001). However, this does not mean that cholinergic interneurons play no role in spiny neuron vulnerability. Using the 3-NP rat and the R6/2 mouse models, a recent study suggested that defective plasticity of cholinergic interneurons could be the primary event mediating abnormal functioning of striatal circuits (Picconi et al., 2006).

\section{Selective neuronal vulnerability in HD}

\subsection{Why are the MSSNs more vulnerable?}

A puzzle in HD is the selective vulnerability of striatal MSSNs and the resistance of interneurons to neurodegeneration. Clearly, multiple factors must contribute to this selective vulnerability. These could include differing levels of expression of huntingtin, differences in the density of NMDA receptors and the degree of cortical innervation, to name a few (Sieradzan and Mann, 2001;Uhl et al., 1988).

One hypothesis is that huntingtin expression differs in various types of neurons and this may account for selective vulnerability. Thus, high levels of expression are confined to neurons and neuropil within the matrix compartment of the striatum, with lower levels of expression in the patch compartment of the striatum (Ferrante et al., 1997). Furthermore, large cholinergic interneurons do not appear to express huntingtin and they do not degenerate, although these findings are controversial (Fusco et al., 1999). What is consistent is that corticostriatal neurons are enriched in huntingtin, suggesting that the HD mutation may render corticostriatal neurons dysfunctional first and potentially destructive upon some MSSNs, rather than render all striatal neurons vulnerable (Fusco et al., 1999). Interestingly, huntingtin is expressed in a higher proportion in substance P-positive neurons forming the direct striatonigral pathway than in the enkephalin-positive neurons forming the indirect striatopallidal output (Fusco et al., 2003).

A growing number of studies have demonstrated differential expression of specific membrane ion channels, glutamate receptor subunits, and intracellular enzymatic activities that could be responsible for opposite glutamate receptor-mediated toxicity between MSSNs and striatal interneurons (Calabresi et al., 2000). There is little doubt that NMDA receptors play an important role in degeneration of MSSNs in HD. Since the cellular distribution, density, and subunit composition of NMDA receptors is not equal throughout the striatum (Landwehrmeyer et al., 1995b), these factors could help explain differential vulnerability. For example, striatal interneurons have reduced density of NMDA receptors and the subunit composition is different from that expressed by MSSNs (Standaert et al., 1999).

Taking advantage of cell identification with infrared videomicroscopy we examined cell swelling induced by NMDA in MSSNs compared to large, putative cholinergic interneurons. We observed that, in contrast to MSSNs, cell swelling was not induced in large interneurons by bath application of NMDA (Cepeda et al., 2001c). This effect was not due to the inability of large interneurons to swell, because kainate application could induce cell swelling. Electrophysiological experiments confirmed reduced NMDA current density in large interneurons (Cepeda et al., 2001c). Although previous reports suggested that cholinergic interneurons were less responsive to all glutamate receptor agonists (Calabresi et al., 1998), our results demonstrated that the reduced sensitivity was not indiscriminate, but specific to activation of NMDA receptors. Similar studies in HD mouse models remain to be done in order to provide confirmatory evidence.

Another factor that could contribute to the selective vulnerability of MSSNs is the degree of cortical innervation (Fusco et al., 1999). Our observations suggest that a progressive 
disconnection between cortex and striatum occurs in HD. We could expect that striatal neurons that receive less cortical inputs would be more resistant to degeneration. At least one class of striatal interneuron, the cholinergic large aspiny cell, which has been shown to be less densely innervated than the MSSNs (Bennet and Wilson, 1999;Cepeda et al., 2001c;Lapper and Bolam, 1992), is spared in HD. This conclusion lends support to the idea that a critical determinant of neuronal vulnerability is the extent to which cells receive input from cortical and other huntingtin-rich glutamate neurons (Fusco et al., 1999).

The question then becomes what is the mechanism of MSSN degeneration in human HD? One potential hypothesis for a mechanism is that early changes in cortical projection neurons alter their ability to release glutamate and possibly BDNF into target areas. This decrease induces changes in postsynaptic glutamate receptor density, distribution, or subunit composition leading to denervation supersensitivity. Although studies reporting this phenomenon in the striatum are relatively rare, one set of experiments on striatal glutamate receptor expression after cortical ablations found evidence for excitatory amino acid receptor changes in gene expression, supporting the concept of denervation supersensitivity (Wüllner et al., 1994). In addition, there is evidence that the composition of postsynaptic NMDA receptors is under tight presynaptic control (Gottman et al., 1997). Alterations in presynaptic activity thus may affect the types of postsynaptic NMDA receptors activated.

Recent studies are attributing an increasingly important role to extrasynaptic NMDA receptors (Kullman and Asztely, 1998). In view of the fact that the number of synaptic contacts may be reduced in $\mathrm{HD}$, the role of these extrasynaptic receptors may be increased. In normal conditions extrasynaptic NMDA receptors appear to signal glutamate spillover [extrasynaptic diffusion of neurotransmitter (Kullman and Asztely, 1998;Lozovaya et al., 1999)]. Receptor subunit composition is different between synaptic and extrasynaptic NMDA receptors. Thus, in hippocampal neurons, extrasynaptic NMDA receptors contain NR1 and NR2B subunits, whereas synaptic NMDA receptors also contain the NR2A subunit (Tovar and Westbrook, 1999). This has led to the suggestion that synaptic and extrasynaptic NMDA receptors may have differing roles in excitotoxicity (Sattler et al., 2000). In support, there is evidence that activation of synaptic and extrasynaptic NMDA receptors have opposing effects on the cAMP response element binding protein (CREB), gene regulation and neuronal survival (Hardingham et al., 2002). Thus, whereas $\mathrm{Ca}^{2+}$ entry through synaptic NMDA receptors induces CREB activity and BDNF gene expression, $\mathrm{Ca}^{2+}$ entry through extrasynaptic NMDA receptors activates a dominant CREB shut-off pathway that blocks induction of BDNF expression (Hardingham et al., 2002). These results imply that synaptic NMDA receptors have antiapoptotic activity, whereas stimulation of extrasynaptic NMDA receptors causes loss of mitochondrial membrane potential and cell death (Hardingham et al., 2002).

Considering that there is a progressive disconnection between the cortex and the striatum, associated with reductions in synaptophysin and PSD95, and knowing that the density of NMDA receptors is not reduced in HD, one reasonable assumption is an increased role of extrasynaptic NMDA receptors as the disease advances. The fact that there is a progressive reduction in synaptic contacts does not mean that glutamate is not being released, it just indicates that the topography of receptor activation is likely to change in HD. Enhanced activation of extrasynaptic NMDA receptors may facilitate cell dysfunction and eventual death. Indeed, recent studies have indicated that reduced expression of PSD95 in neurons may be responsible for neuronal vulnerability (Gardoni et al., 2002).

Finally, another factor that affects neuronal vulnerability is the presence or absence of dendritic spines. We do not know the cause of the progressive loss of spines in transgenic HD mice (Klapstein et al., 2001). We can only speculate that early dysregulation of glutamate release, manifested by the presence of large synaptic events, in conjunction with an increase in cortical 
excitability, may induce postsynaptic changes. Studies of hippocampal neurons show that exposure to glutamate or NMDA for short periods of time can produce a rapid loss of dendritic spines (Halpain et al., 1998). However, a decrease in synaptic activity observed in later stages of the disease, could also cause elimination of spines (Segal, 1995). Whatever the mechanism of spine elimination in R6/2 transgenics, one consequence of spine loss is to make these neurons more vulnerable to subsequent excitotoxic stimuli (Halpain et al., 1998). In that sense spines, as well as normal levels of synaptic activity, can be viewed as neuroprotective (Segal, 1995). Supporting this suggestion, it has recently been shown that environmental stimulation can increase the life expectancy of R6/2 and R6/1 mice (Carter et al., 2000; Hockly et al., 2002; van Dellen et al., 2000) and prevents the occurrence of seizures. Environmental stimulation increases spine density (Schrott, 1997) and possibly reduces the rate of spine loss in MSSNs in HD.

\subsection{Selective vulnerability of enkephalin-containing cells}

What makes MSSNs originating the indirect pathway more vulnerable in HD? Taking advantage of the generation of mice expressing enhanced green fluorescent protein (EGFP) in cells containing dopamine D1 (direct pathway) or D2 (indirect pathway) receptors (Gong et al., 2003), we were able to tease apart electrophysiological properties specific to each cell type. For example, D2-EGFP cells displayed more spontaneous inward synaptic currents than D1EGFP cells and large-amplitude events (similar in amplitude, but not identical to those seen transiently in a subset of MSSNs from R6/2 mice) occurred only in D2 cells (Cepeda et al., 2004b). This means that D1- and D2-EGFP-positive MSSNs differ in the type of synaptic inputs they receive. Increased frequency of small-amplitude synaptic currents could indicate increased inputs and glutamate release on D2 cells. Large-amplitude synaptic events are usually dependent on the firing of action potentials from the presynaptic neuron, indicating that D2 cells more faithfully reflect ongoing cortical activity.

These findings are reinforced by anatomical data demonstrating that the size of corticostriatal terminals making synaptic contacts with D2-immunolabeled spines is significantly larger than those making contact with D1-immunolabeled spines (Lei et al., 2004). The idea that D2 cells receive more glutamatergic input was also reinforced by the observation that application of $\mathrm{GABA}_{\mathrm{A}}$ receptor antagonists induced large-amplitude membrane depolarizations preferentially in $\mathrm{D} 2$ cells. These depolarizations reflect increased cortical synchronization typically produced by blockade of $\mathrm{GABA}_{\mathrm{A}}$ receptors. The preferential propagation of epileptiform activity onto $\mathrm{D} 2$ cells thus confirms a tighter synaptic coupling between cortical pyramidal neurons and this particular subpopulation of MSSNs, in support of previous data demonstrating that enkephalin-positive neurons are selectively activated by cortical stimulation (Berretta et al., 1997) and that preproenkephalin expression is under the control of cortical inputs (Uhl et al., 1988).

These findings could help explain the observation that in HD the striatal projection to the external pallidal segment (indirect pathway) is the most vulnerable (Deng et al., 2004). One of the earliest morphological changes in HD is the reduction in enkephalin expression in neurons of the indirect pathway (Menalled et al., 2000;Reiner et al., 1988;Sapp et al., 1995). Our electrophysiological studies in R6/2 mice have demonstrated a transient increase (around 5-7 weeks) of large synaptic events in a subset of MSSNs followed by a progressive reduction of cortical inputs into the striatum (Cepeda et al., 2003). It is tempting to speculate that the transient surge occurs primarily on the D2 (enkephalin-expressing) neurons because these neurons have greater cortical synaptic inputs and are more directly affected by cortical activity. Thus, these D2-expressing neurons would be more vulnerable to dysfunction in the corticostriatal pathway. 


\section{Rescuing synaptic dysfunction}

How can these findings on corticostriatal synaptic dysfunction help design a more rational treatment for HD? A number of important considerations have to be taken into account to answer this question. First, timing is of paramount importance. Data from multiple laboratories indicate that cellular and synaptic alterations occur very early in genetic mouse models of HD, often before overt symptoms or major neuropathological changes can be observed (Levine et al., 2004). This fact offers a unique opportunity for intervention. Second, regional alterations (e.g., cortex versus striatum) are also important. Should we try to reduce cortical hyperexcitability or should we try to rescue the progressive decline in spontaneous synaptic activity in the striatum? How can we prevent selectively the increased NMDA receptor sensitivity of striatal neurons? If, according to the chain reaction model there is a single, probably cortical, trigger of striatal dysfunction we could concentrate on preventing this primary alteration. However, if changes in the intrinsic membrane properties of MSSNs are the primary event, it is possible that targeting the cortical pyramidal neurons would be fruitless. It has been generally assumed that treatment of HD should be aimed at reducing glutamate release in the corticostriatal pathway. But as we demonstrated, with disease progression, synaptic activity decreases until the striatum becomes functionally disconnected from the cortex. Thus, reducing glutamate release at this stage would not be effective. Furthermore, reducing glutamate release deprives the striatum of important neurotrophic factors. However, reducing glutamate release when the first signs of dysregulation in the corticostriatal pathway occur could be therapeutic.

\subsection{Drugs that reduce cortical excitability and glutamate release}

If the cortex becomes hyperexcitable in HD (Cepeda et al., 2003;Cummings et al., 2006b;Gu et al., 2005; Uzgil et al., 2004), drugs that reduce cortical neuronal excitability must be beneficial. Indeed, drugs that reduce glutamate release, such as riluzole, can be neuroprotective both in clinical trials and in animal models of HD (Centonze et al., 1998;Cepeda et al., 2003; Huntington Study Group, 2003;Mary et al., 1995;Rosas et al., 1999; Schiefer et al., 2002b). Furthermore, a short-acting benzodiazepine, alprazolam improved cognitive function in a mouse model of HD (A. J. Morton, personal communication). The fact that benzodiazepines are allosteric agonists that increase $\mathrm{GABA}_{\mathrm{A}}$ receptor mediated inhibition explains that this drug also has antiepileptic properties (Kubova and Mares, 1993). Activation of group II mGluRs, either on striatal cells or presynaptic corticostriatal terminals, has neuroprotective effects in the quinolinic acid model (Orlando et al., 1995). In addition, group I mGluRs play a major role as antagonism of these receptors can be also neuroprotective (Orlando et al., 2001). In the R6/2 model both a $\mathrm{mGluR}_{2}$ agonist or a $\mathrm{mGluR}_{5}$ antagonist increased survival time compared to placebo treated transgenic animals (Schiefer et al., 2004). The relative success in this trial can be attributed to prompt initiation of treatment at 3.5 weeks of age.

Electrophysiological studies have provided evidence for presynaptic regulation of glutamate release by D2 receptors either directly (Bamford et al., 2004;Cepeda et al., 2001b;FloresHernandez et al., 1997; Hsu et al., 1995) or via a retrograde signal involving endocannabinoid production and activation of presynaptic $\mathrm{CB}_{1}$ receptors (Yin and Lovinger, 2006). As dopamine release may be compromised in $\mathrm{HD}$, and dopamine receptors are decreased early in the disease, attempts to restore or enhance dopamine function have been assessed. Apomorphine, a D1/D2 receptor agonist, seemed to ameliorate HD symptoms (Albanese et al., 1995;Corsini et al., 1978). In the R6/2 model, replacement therapy with L-DOPA caused short-term behavioral improvements but long-term treatment was deleterious on survival and rotarod performance (Hickey et al., 2002). Dopamine D2 receptor blockers do not appear to affect the long-term progression of HD. Bromocriptine, rather than improving chorea, induced an exacerbation 
(Kartzinet et al., 1976). However, dose-dependent effects were also observed. Low doses produced clinical improvement but higher doses potentiated the symptoms (Loeb et al., 1979). Finally, another D2 blocker, sulpiride, produced no functional improvement but reduced abnormal movements (Quinn and Marsden, 1984). In contrast, there is growing consensus that D2 agonists are neuroprotective, probably by pre- and postsynaptic mechanisms, and could be used to prevent striatal neuronal damage (Bozzi and Borrelli, 2006;Cepeda et al., 1998).

Because of early alterations in adenosine receptor signaling in HD (Tarditi et al., 2006), the potential therapeutic effects of adenosine receptor agonists or antagonists are beginning to be examined (Blum et al., 2003a). In the 3-NP model administration of an $\mathrm{A}_{1}$ receptor agonist, ADAC prevented the development of dystonia (Blum et al., 2002). In addition, another agonist was able to reduce 3-NP-induced seizures in mice (Zuchora et al., 2001) via disruption of glutamate neurotransmission. The role of $\mathrm{A}_{2 \mathrm{~A}}$ receptors is more complex, as these receptors have a pre- and postsynaptic distribution that could result in biphasic effects (Blum et al., 2003b). Blockade of presynaptic $A_{2 A}$ receptors has been proved beneficial in a number of neurological conditions, including HD (Popoli et al., 2002). On the other hand, activation of postsynaptic $\mathrm{A}_{2 \mathrm{~A}}$ receptors has potential therapeutic effects. For example, in the R6/2 model, administration of CGS21680, an $\mathrm{A}_{2 \mathrm{~A}}$ adenosine receptor selective agonist, delayed the progressive deterioration of motor performance and prevented a reduction in brain weight (Chou et al., 2005).

Alterations in endocannabinoid receptors occur early in mouse models of HD. In R6/1 transgenic mice $\mathrm{CB}_{1}$ receptor mRNA is severely downregulated between 8-10 weeks of age, before overt symptoms occur (McCaw et al., 2004;Naver et al., 2003). Importantly, as shown in another mouse model, the decrease in $\mathrm{CB}_{1}$ receptor levels is accompanied by a decrease in proenkephalin- but not in substance P-mRNA levels, suggesting that the loss of $\mathrm{CB}_{1}$ receptors might be preferential to striatopallidal neurons (Lastres-Becker et al., 2002). These data demonstrating that the endocannabinoid system becomes hypofunctional in HD open a new venue for therapeutic intervention using highly selective $\mathrm{CB}_{1}$ agonists (Lastres-Becker et al., 2003).

Our results on changes in GABA synaptic activity are applicable to studies testing the efficacy of GABA mimetic compounds in the treatment of HD. Although some can reduce dystonia, at least in animal models (Hamann and Richter, 2002), for the most part clinical trials have been unsuccessful (Shoulson et al., 1978; Waddington and Cross, 1984). Specifically, in spite of early reports of limited success in retarding disease progression using baclofen, a $\mathrm{GABA}_{B}$ receptor agonist, controlled trials have been unsuccessful, casting doubt on the efficacy of reducing presynaptic release of glutamate (Shoulson et al., 1989). This is not unexpected in view of our findings showing increased GABAergic tone and reduced glutamate synaptic activity in mouse models. Interestingly, abnormal sensitivity of endocannabinoid receptors may contribute to aberrant GABA synaptic transmission (Centonze et al., 2005).

\subsection{Manipulating BDNF}

Another promising therapeutic venue is to restore trophic factors lost because of the progressive decrease in cortical inputs. Decreased striatal BDNF has been reported in HD mouse models and may contribute to cell dysfunction (Zuccato et al., 2001). Normal huntingtin contributes to the BDNF pool produced in the cerebral cortex and its loss affects the stability of cortical afferents and decreases support to striatal targets (Cattaneo et al., 2005). Furthermore, normal huntingtin enhances vesicular transport of BDNF and this transport is markedly attenuated in the context of HD (Gauthier et al., 2004). The expression of TrkB, the principal BDNF receptor, is also severely reduced in HD (Gines et al., 2006). Finally, mice that lack cortical BDNF develop progressive symptoms and neuropathology similar to that found in HD (Baquet et al., 2004). 
Among a growing number of therapeutic trials, attempts to restore neurotrophic factors in HD models have yielded promising results (Alberch et al., 2004;Zucatto et al., 2005). In fact, dietary restriction (Duan et al., 2003), as well as several candidate drugs to treat HD such as cisteamine (Borrell-Pages et al., 2006) and riluzole (Mizuta et al., 2001), appears to be neuroprotective via increasing BDNF levels in the brain. Biologically delivered neurotrophins can also attenuate striatal damage caused by 3-NP (Frim et al., 1993) or quinolinic acid (Alberch et al., 2002;Perez-Navarro et al., 2000). Furthermore, environmental enrichment can slow the progression of the disease in R6/2 mice (Hockly et al., 2002) presumably, among other factors, by increasing BDNF levels. A key component of environmental enrichment is exercise, which is known to increase BDNF levels (Cotman and Berchtold 2002) and is being considered as a potential tool for slowing progression of some neurodegenerative diseases (Smith and Zigmond, 2003). In the R6/1 model of HD, voluntary exercise delays the onset of behavioral and cognitive deficits, although the exact relationship with BDNF protein levels was not established (Pang et al., 2006). Recently we began to examine the effects of exercise on electrophysiological parameters known to be altered in R6/2 mice. In transgenic mice, there is a significant reduction in membrane capacitance of MSSNs, probably associated with a reduction in spine density and dendritic branching. After 3-5 weeks of voluntary exercise, the decrease in cell membrane capacitance was rescued, suggesting that exercise may prevent the loss of membrane observed in HD mice. In contrast, the progressive reduction in spontaneous synaptic currents did not appear changed by exercise, possibly due to the fact that transgenic mice exercise much less than wildtype animals (Cepeda et al., 2006; Hickey et al., 2005).

Despite this finding, further exploration into the effects of BDNF on corticostriatal synaptic transmission is warranted. Interestingly, voluntary exercise markedly increased spontaneous synaptic currents in control mice.

Evidence indicates that bath application of BDNF produces differential effects on spontaneous synaptic activity. It increases glutamatergic (Li et al., 1998) but decreases GABAergic currents (Tanaka et al., 1997). In that sense, BDNF could be ideal because it could rescue the progressive decline in glutamatergic currents and, at the same time, prevent the increase in GABA currents. We showed that BDNF reduced GABAergic currents in R6/2 mice (Cepeda et al., 2004a). This effect could be caused by changes in receptor expression. In hippocampal cultures, BDNF reduces miniature inhibitory postsynaptic currents by rapid down-regulation of $\mathrm{GABA}_{\mathrm{A}}$ receptor surface expression (Brünig et al., 2001). Thus, it becomes important to test whether or not BDNF can fully restore normal striatal synaptic function in HD.

\section{Conclusions}

Evidence obtained from genetic mouse models of HD has changed our views about how the symptoms of this disorder emerge. First, neuronal dysfunction is sufficient to induce symptoms (Tobin and Signer, 2000;Levine et al., 2004) and cell death is not a prerequisite for their occurrence. Second, neuronal circuits in both the striatum and cortex are important in the development of the HD phenotype. The corticostriatal pathway is the primary provider of the excitatory glutamatergic inputs into the striatum. The effects of these inputs are regulated by presynaptic receptors on corticostriatal terminals that function as the gatekeepers of glutamate release, as well as by the intrinsic membrane properties of MSSNs. When the neurons of this pathway become dysfunctional, excitation of striatal neurons will become abnormal. Furthermore, it is becoming increasingly clear that major morphological alterations in the striatum are probably primed initially by alterations in the intrinsic functional properties of MSSNs, but ultimately require abnormalities in corticostriatal inputs for the phenotype to be expressed. When viewed in this context, reasons for the selective degeneration of MSSNs and the earlier predisposition to loss of MSSNs in the indirect striatal output pathway become apparent. 
The changes within the corticostriatal pathway are just beginning to be unraveled. They are complex and consist of early increased excitability which may involve a combination of changes in inhibitory GABAergic cortical microcircuits and presynaptic dysregulation of neurotransmitter release, followed by a loss of connectivity between the cortex and striatum. This sequence of events also may cause increased striatal GABA function which will severely impair the integrative and output capabilities of MSSNs and cause a lack of regulation of pallidal and nigral neurons. From a clinical perspective, early disturbances of cortical function point to potential mechanisms underlying the cognitive and emotional abnormalities associated with the disorder that often precede the sensorimotor symptoms. Alterations in striatal output, in the absence of significant cell loss, will ultimately lead to the disruption of sensorimotor control. Taken together, the primary implications from these conclusions are that interventions to ameliorate or ultimately prevent the development of the HD phenotype should occur early to target neuronal dysfunction and should be aimed at abnormalities in both cortex and striatum.

\section{Acknowledgements}

This work was supported by grants and contracts from the USPHS (NS41574), the Hereditary Disease Foundation, the High Q Foundation, and the Cure HD Initiative. We would like to thank our collaborators at the MRRC, in particular Drs. Prasad R. Joshi and Joshua Plotkin for their work in HD mouse models and for helpful comments on the manuscript.

\section{References}

Aizman O, Brismar H, Uhlen P, Zettergren E, Levey AI, Forssberg H, Greengard P, Aperia A. Anatomical and physiological evidence for D1 and D2 dopamine receptor colocalization in neostriatal neurons. Nat Neurosci 2000;3:226-230. [PubMed: 10700253]

Albanese A, Cassetta E, Carretta D, Bentivoglio AR, Tonali P. Acute challenge with apomorphine in Huntington's disease: a double-blind study. Clin Neuropharmacol 1995;18:427-434. [PubMed: 8665556]

Alberch J, Perez-Navarro E, Canals JM. Neuroprotection by neurotrophins and GDNF family members in the excitotoxic model of Huntington's disease. Brain Res Bull 2002;57:817-822. [PubMed: 12031278]

Alberch J, Perez-Navarro E, Canals JM. Neurotrophic factors in Huntington's disease. Prog Brain Res 2004;146:195-229. [PubMed: 14699966]

Albin RL, Young AB, Penney JB. The functional anatomy of basal ganglia disorders. Trends Neurosci 1989;12:366-375. [PubMed: 2479133]

Ali NJ, Levine MS. Changes in expression of N-methyl-D-aspartate receptor subunits occur early in the R6/2 mouse model of Huntington's disease. Dev Neurosci 2006;28:230-238. [PubMed: 16679770]

André VM, Cepeda C, Venegas A, Gomez Y, Levine MS. Altered cortical glutamate receptor function in the R6/2 model of Huntington's disease. J Neurophysiol 2006;95:2108-2119. [PubMed: 16381805]

Ariano MA, Aronin N, Difiglia M, Tagle DA, Sibley DR, Leavitt BR, Hayden MR, Levine MS. Striatal neurochemical changes in transgenic models of Huntington's disease. J Neurosci Res 2002;68:716729. [PubMed: 12111832]

Ariano MA, Cepeda C, Calvert CR, Flores-Hernandez J, Hernandez-Echeagaray E, Klapstein GJ, Chandler SH, Aronin N, DiFiglia M, Levine MS. Striatal potassium channel dysfunction in Huntington's disease transgenic mice. J Neurophysiol 2005a;93:2565-2574. [PubMed: 15625098]

Ariano MA, Wagle N, Grissell AE. Neuronal vulnerability in mouse models of Huntington's disease: membrane channel protein changes. J Neurosci Res 2005b;80:634-645. [PubMed: 15880743]

Ayalon L, Doron R, Weiner I, Joel D. Amelioration of behavioral deficits in a rat model of Huntington's disease by an excitotoxic lesion to the globus pallidus. Exp Neurol 2004;186:46-58. [PubMed: 14980809]

Bamford NS, Zhang H, Schmitz Y, Wu NP, Cepeda C, Levine MS, Schmauss C, Zakharenko SS, Zablow L, Sulzer D. Heterosynaptic dopamine neurotransmission selects sets of corticostriatal terminals. Neuron 2004;42:653-663. [PubMed: 15157425] 
Baquet ZC, Gorski JA, Jones KR. Early striatal dendrite deficits followed by neuron loss with advanced age in the absence of anterograde cortical brain-derived neurotrophic factor. J Neurosci 2004;24:4250-4258. [PubMed: 15115821]

Bates, GP.; Murphy, KP. Mouse models of Huntington's disease. In: Bates, GP.; Harper, PS.; Jones, AL., editors. Huntington's Disease. Oxford University Press; Oxford, U.K.: 2002. p. 387-426.

Beal MF, Kowall NW, Ellison DW, Mazurek MF, Swartz KJ, Martin JB. Replication of the neurochemical characteristics of Huntington's disease by quinolinic acid. Nature 1986;321:168-171. [PubMed: 2422561]

Behrens PF, Franz P, Woodman B, Lindenberg KS, Landwehrmeyer GB. Impaired glutamate transport and glutamate-glutamine cycling: downstream effects of the Huntington mutation. Brain 2002;125:1908-1922. [PubMed: 12135980]

Bennett BD, Bolam JP. Synaptic input and output of parvalbumin-immunoreactive neurons in the neostriatum of the rat. Neuroscience 1994;62:707-719. [PubMed: 7870301]

Bennett BD, Wilson CJ. Spontaneous activity of neostriatal cholinergic interneurons in vitro. J Neurosci 1999;19:5586-5596. [PubMed: 10377365]

Berretta S, Parthasarathy HB, Graybiel AM. Local release of GABAergic inhibition in the motor cortex induces immediate-early gene expression in indirect pathway neurons of the striatum. J Neurosci 1997;17:4752-4763. [PubMed: 9169535]

Bibb JA, Yan Z, Svenningsson P, Snyder GL, Pieribone VA, Horiuchi A, Nairn AC, Messer A, Greengard P. Severe deficiencies in dopamine signaling in presymptomatic Huntington's disease mice. Proc Natl Acad Sci USA 2000;97:6809-6814. [PubMed: 10829080]

Bizière K, Coyle JT. Effects of cortical ablation on the neurotoxicity and receptor binding of kainic acid in striatum. J Neurosci Res 1979;4:383-398. [PubMed: 42811]

Blum D, Gall D, Galas MC, d'Alcantara P, Bantubungi K, Schiffmann SN. The adenosine A1 receptor agonist adenosine amine congener exerts a neuroprotective effect against the development of striatal lesions and motor impairments in the 3-nitropropionic acid model of neurotoxicity. J Neurosci 2002;22:9122-9133. [PubMed: 12388620]

Blum D, Hourez R, Galas MC, Popoli P, Schiffmann SN. Adenosine receptors and Huntington's disease: implications for pathogenesis and therapeutics. Lancet Neurol 2003a;2:366-374. [PubMed: 12849153]

Blum D, Galas MC, Pintor A, Brouillet E, Ledent C, Muller CE, Bantubungi K, Galluzzo M, Gall D, Cuvelier L, Rolland AS, Popoli P, Schiffmann SN. A dual role of adenosine A2A receptors in 3 nitropropionic acid-induced striatal lesions: implications for the neuroprotective potential of A2A antagonists. J Neurosci 2003b;23:5361-5369. [PubMed: 12832562]

Borrell-Pages M, Canals JM, Cordelieres FP, Parker JA, Pineda JR, Grange G, Bryson EA, Guillermier M, Hirsch E, Hantraye P, Cheetham ME, Neri C, Alberch J, Brouillet E, Saudou F, Humbert S. Cystamine and cysteamine increase brain levels of BDNF in Huntington disease via HSJ1b and transglutaminase. J Clin Invest 2006;116:1410-1424. [PubMed: 16604191]

Bozzi Y, Borrelli E. Dopamine in neurotoxicity and neuroprotection: what do D2 receptors have to do with it? Trends Neurosci 2006;29:167-174. [PubMed: 16443286]

Brouillet E, Condé F, Beal MF, Hantraye P. Replicating Huntington's disease phenotype in experimental animals. Prog Neurobiol 1999;59:427-468. [PubMed: 10515664]

Brünig I, Penschuck S, Berninger B, Benson J, Fritschy JM. BDNF reduces miniature inhibitory postsynaptic currents by rapid downregulation of $\mathrm{GABA}_{\mathrm{A}}$ receptor surface expression. Eur $\mathrm{J}$ Neurosci 2001;13:1320-1328. [PubMed: 11298792]

Calabresi P, Mercuri NB, De Murtas M, Bernardi G. Endogenous GABA mediates presynaptic inhibition of spontaneous and evoked excitatory synaptic potentials in the rat neostriatum. Neurosci Lett 1990;118:99-102. [PubMed: 2259476]

Calabresi P, Centonze D, Pisani A, Sancesario G, Gubellini P, Marfia GA, Bernardi G. Striatal spiny neurons and cholinergic interneurons express differential ionotropic glutamatergic responses and vulnerability: implications for ischemia and Huntington's disease. Ann Neurol 1998;43:586-597. [PubMed: 9585352]

Calabresi P, Centonze D, Bernardi G. Cellular factors controlling neuronal vulnerability in the brain: a lesson from the striatum. Neurology 2000;55:1249-1255. [PubMed: 11092223] 
Calabresi P, Gubellini P, Picconi B, Centonze D, Pisani A, Bonsi P, Greengard P, Hipskind RA, Borrelli E, Bernardi G. Inhibition of mitochondrial complex II induces a long-term potentiation of NMDAmediated synaptic excitation in the striatum requiring endogenous dopamine. J Neurosci 2001;21:5110-5120. [PubMed: 11438586]

Carlsson A, Falck B, Hillarp NA. Cellular localization of brain monoamines. Acta Physiol Scand 1962;56 (Suppl 196):1-28. [PubMed: 14027625]

Carter RJ, Lione LA, Humby T, Mangiarini L, Mahal A, Bates GP, Dunnett SB, Morton AJ. Characterization of progressive motor deficits in mice transgenic for the human Huntington's disease mutation. J Neurosci 1999;19:3248-3257. [PubMed: 10191337]

Carter RJ, Hunt MJ, Morton AJ. Environmental stimulation increases survival in mice transgenic for exon 1 of the Huntington's disease gene. Mov Disord 2000;15:925-937. [PubMed: 11009201]

Cattaneo E, Rigamonti D, Goffredo D, Zuccato C, Squitieri F, Sipione S. Loss of normal huntingtin function: new developments in Huntington's disease research. Trends Neurosci 2001;24:182-188. [PubMed: 11182459]

Cattaneo E, Zuccato C, Tartari M. Normal huntingtin function: an alternative approach to Huntington's disease. Nat Rev Neurosci 2005;6:919-930. [PubMed: 16288298]

Centonze D, Calabresi P, Pisani A, Marinelli S, Marfia GA, Bernardi G. Electrophysiology of the neuroprotective agent riluzole on striatal spiny neurons. Neuropharmacology 1998;37:1063-1070. [PubMed: 9833635]

Centonze D, Gubellini P, Picconi B, Saulle E, Tolu M, Bonsi P, Giacomini P, Calabresi P. An abnormal striatal synaptic plasticity may account for the selective neuronal vulnerability in Huntington's disease. Neurol Sci 2001;22:61-62. [PubMed: 11487202]

Centonze D, Rossi S, Prosperetti C, Tscherter A, Bernardi G, Maccarrone M, Calabresi P. Abnormal sensitivity to cannabinoid receptor stimulation might contribute to altered gamma-aminobutyric acid transmission in the striatum of R6/2 Huntington's disease mice. Biol Psychiatry 2005;57:1583-1589. [PubMed: 15953496]

Cepeda C, Levine MS. Dopamine and N-methyl-D-aspartate receptor interactions in the neostriatum. Dev Neurosci 1998;20:1-18. [PubMed: 9600386]

Cepeda C, Levine MS. Where do you think you are going? The NMDA-D1 receptor trap. Sci STKE 2006;333:pe20. [PubMed: 16670371]

Cepeda C, Ariano MA, Calvert CR, Flores-Hernandez J, Chandler SH, Leavitt BR, Hayden MR, Levine MS. NMDA receptor function in mouse models of Huntington disease. J Neurosci Res 2001a;66:525539. [PubMed: 11746372]

Cepeda C, Hurst RS, Altemus KL, Flores-Hernandez J, Calvert CR, Jokel ES, Grandy DK, Low MJ, Rubinstein M, Ariano MA, Levine MS. Facilitated glutamatergic transmission in the striatum of D2 dopamine receptor-deficient mice. J Neurophysiol 2001b;85:659-670. [PubMed: 11160501]

Cepeda C, Itri JN, Flores-Hernández J, Hurst RS, Calvert CR, Levine MS. Differential sensitivity of medium- and large-sized striatal neurons to NMDA but not kainate receptor activation in the rat. Eur J Neurosci 2001c;14:1577-1589. [PubMed: 11860453]

Cepeda C, Hurst RS, Calvert CR, Hernandez-Echeagaray E, Nguyen OK, Jocoy E, Christian LJ, Ariano MA, Levine MS. Transient and progressive electrophysiological alterations in the corticostriatal pathway in a mouse model of Huntington's disease. J Neurosci 2003;23:961-969. [PubMed: 12574425]

Cepeda C, Starling AJ, Wu N, Nguyen OK, Uzgil B, Soda T, Andre VM, Ariano MA, Levine MS. Increased GABAergic function in mouse models of Huntington's disease: reversal by BDNF. J Neurosci Res 2004a;78:855-867. [PubMed: 15505789]

Cepeda C, Starling AJ, Wu N, Soda T, Lobo MK, Yang XW, Levine MS. Defining electrophysiological properties of subpopulations of striatal neurons using genetic expression of enhanced green fluorescent protein. Soc Neurosci Abst 2004b;30:307.4.

Cepeda CMA, Hickey MA, Kleiman-Weiner M, Yamazaki I, Wu N, Beroukhim B, Watson JB, Levine MS. Effects of voluntary exercise on the Huntington's disease phenotype in the R6/2 mouse model. Soc Neurosci Abstr. 2006In Press 
Cha JH, Kosinski CM, Kerner JA, Alsdorf SA, Mangiarini L, Davies SW, Penney JB, Bates GP, Young AB. Altered brain neurotransmitter receptors in transgenic mice expressing a portion of an abnormal human huntington disease gene. Proc Natl Acad Sci USA 1998;95:6480-6485. [PubMed: 9600992]

Charara A, Heilman TC, Levey AI, Smith Y. Pre- and postsynaptic localization of GABA B receptors in the basal ganglia in monkeys. Neuroscience 2000;95:127-140. [PubMed: 10619469]

Charpier S, Deniau JM. In vivo activity-dependent plasticity at cortico-striatal connections: evidence for physiological long-term potentiation. Proc Natl Acad Sci USA 1997;94:7036-7040. [PubMed: 9192687]

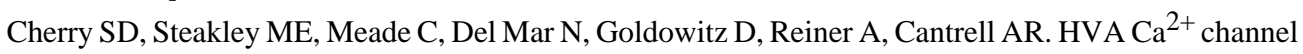
activity is upregulated in cortical neurons in R6/2 Huntington's disease (HD) transgenic mice. Soc Neurosci Abstr. 2002Program No. 92.13

Chou SY, Lee YC, Chen HM, Chiang MC, Lai HL, Chang HH, Wu YC, Sun CN, Chien CL, Lin YS, Wang SC, Tung YY, Chang C, Chern Y. CGS21680 attenuates symptoms of Huntington's disease in a transgenic mouse model. J Neurochem 2005;93:310-320. [PubMed: 15816854]

Cicchetti F, Gould PV, Parent A. Sparing of striatal neurons coexpressing calretinin and substance P (NK1) receptor in Huntington's disease. Brain Res 1996;730:232-237. [PubMed: 8883909]

Corsini GU, Onali P, Masala C, Cianchetti C, Mangoni A, Gessa G. Apomorphine hydrochloride-induced improvement in Huntington's chorea: stimulation of dopamine receptor. Arch Neurol 1978;35:2730. [PubMed: 145840]

Cotman CW, Berchtold NC. Exercise: a behavioral intervention to enhance brain health and plasticity. Trends Neurosci 2002;25:295-301. [PubMed: 12086747]

Cudkowicz M, Kowall NW. Degeneration of pyramidal projection neurons in Huntington's disease cortex. Ann Neurol 1990;27:200-204. [PubMed: 2138444]

Cummings DM, Milnerwood AJ, Dallérac GM, Waights V, Brown JY, Vatsavayai SC, Hirst MC, Murphy KPSJ. Aberrant cortical synaptic plasticity and dopaminergic dysfunction in a mouse model of Huntington's disease. Hum Mol Genet 2006a;15:2856-2868. [PubMed: 16905556]

Cummings DM, Uzgil BO, Marcolino BF, André VM, Cepeda C, Levine MS. Reduced GABAergic inhibition in the cortex of the R6/2 mouse model of Huntington's disease. Soc Neurosci Abstr. 2006bIn Press

Dalbem A, Silveira CV, Pedroso MF, Breda RV, Werne Baes CV, Bartmann AP, da Costa JC. Altered distribution of striatal activity-dependent synaptic plasticity in the 3-nitropropionic acid model of Huntington's disease. Brain Res 2005;1047:148-158. [PubMed: 15901483]

Davies SW, Turmaine M, Cozens BA, DiFiglia M, Sharp AH, Ross CA, Scherzinger E, Wanker EE, Mangiarini L, Bates GP. Formation of neuronal intranuclear inclusions underlies the neurological dysfunction in mice transgenic for the HD mutation. Cell 1997;90:537-548. [PubMed: 9267033]

de la Monte SM, Vonsattel JP, Richardson EP Jr. Morphometric demonstration of atrophic changes in the cerebral cortex, white matter, and neostriatum in Huntington's disease. J Neuropathol Exp Neurol 1988;47:516-525. [PubMed: 2971785]

Deng YP, Albin RL, Penney JB, Young AB, Anderson KD, Reiner A. Differential loss of striatal projection systems in Huntington's disease: a quantitative immunohistochemical study. J Chem Neuroanat 2004;27:143-164. [PubMed: 15183201]

Diaz-Hernandez M, Torres-Peraza J, Salvatori-Abarca A, Moran MA, Gomez-Ramos P, Alberch J, Lucas JJ. Full motor recovery despite striatal neuron loss and formation of irreversible amyloid-like inclusions in a conditional mouse model of Huntington's disease. J Neurosci 2005;25:9773-9781. [PubMed: 16237181]

DiFiglia M. Excitotoxic injury of the neostriatum: a model for Huntington's disease. Trends Neurosci 1990;13:286-289. [PubMed: 1695405]

DiFiglia M, Sapp E, Chase K, Schwarz C, Meloni A, Young C, Martin E, Vonsattel JP, Carraway R, Reeves SA, Boyce FM, Aronin N. Huntingtin is a cytoplasmic protein associated with vesicles in human and rat brain neurons. Neuron 1995;14:1075-1081. [PubMed: 7748555]

DiFiglia M, Sapp E, Chase KO, Davies SW, Bates GP, Vonsattel JP, Aronin N. Aggregation of huntingtin in neuronal intranuclear inclusions and dystrophic neurites in brain. Science 1997;277:1990-1993. [PubMed: 9302293] 
Dos Santos Villar F, Walsh JP. Modulation of long-term synaptic plasticity at excitatory striatal synapses. Neuroscience 1999;90:1031-1041. [PubMed: 10218802]

Duan W, Guo Z, Jiang H, Ware M, Li XJ, Mattson MP. Dietary restriction normalizes glucose metabolism and BDNF levels, slows disease progression, and increases survival in huntingtin mutant mice. Proc Natl Acad Sci USA 2003;100:2911-2916. [PubMed: 12589027]

Ferrante RJ, Gutekunst CA, Persichetti F, McNeil SM, Kowall NW, Gusella JF, MacDonald ME, Beal MF, Hersch SM. Heterogeneous topographic and cellular distribution of huntingtin expression in the normal human neostriatum. J Neurosci 1997;17:3052-3063. [PubMed: 9096140]

Fino E, Glowinski J, Venance L. Bidirectional activity-dependent plasticity at corticostriatal synapses. J Neurosci 2005;25:11279-11287. [PubMed: 16339023]

Flores-Hernandez J, Galarraga E, Bargas J. Dopamine selects glutamatergic inputs to neostriatal neurons. Synapse 1997;25:185-195. [PubMed: 9021899]

Fonnum F, Storm-Mathisen J, Divac I. Biochemical evidence for glutamate as a neurotransmitter in corticostriatal and corticothalamic fibres in rat brain. Neuroscience 1981;6:863-873. [PubMed: 6113562]

Frim DM, Simpson J, Uhler TA, Short MP, Bossi SR, Breakefield XO, Isacson O. Striatal degeneration induced by mitochondrial blockade is prevented by biologically delivered NGF. J Neurosci Res 1993;35:452-458. [PubMed: 8103116]

Fusco FR, Chen Q, Lamoreaux WJ, Figueredo-Cardenas G, Jiao Y, Coffman JA, Surmeier DJ, Honig MG, Carlock LR, Reiner A. Cellular localization of huntingtin in striatal and cortical neurons in rats: lack of correlation with neuronal vulnerability in Huntington's disease. J Neurosci 1999;19:11891202. [PubMed: 9952397]

Fusco FR, Martorana A, De March Z, Viscomi MT, Sancesario G, Bernardi G. Huntingtin distribution among striatal output neurons of normal rat brain. Neurosci Lett 2003;339:53-56. [PubMed: 12618299]

Gardoni F, Bellone C, Viviani B, Marinovich M, Meli E, Pellegrini-Giampietro DE, Cattabeni F, Di Luca M. Lack of PSD-95 drives hippocampal neuronal cell death through activation of an alpha CaMKII transduction pathway. Eur J Neurosci 2002;16:777-786. [PubMed: 12372013]

Gauthier LR, Charrin BC, Borrell-Pages M, Dompierre JP, Rangone H, Cordelieres FP, De Mey J, MacDonald ME, Lessmann V, Humbert S, Saudou F. Huntingtin controls neurotrophic support and survival of neurons by enhancing BDNF vesicular transport along microtubules. Cell 2004;118:127138. [PubMed: 15242649]

Gencik M, Hammans C, Strehl H, Wagner N, Epplen JT. Chorea Huntington: a rare case with childhood onset. Neuropediatrics 2002;33:90-92. [PubMed: 12075490]

Gerdeman G, Lovinger DM. CB1 cannabinoid receptor inhibits synaptic release of glutamate in rat dorsolateral striatum. J Neurophysiol 2001;85:468-471. [PubMed: 11152748]

Gerfen CR. The neostriatal mosaic: multiple levels of compartmental organization. Trends Neurosci 1992;15:133-139. [PubMed: 1374971]

Gibson HE, Reim K, Brose N, Morton AJ, Jones S. A similar impairment in CA3 mossy fibre LTP in the R6/2 mouse model of Huntington's disease and in the complexin II knockout mouse. Eur J Neurosci 2005;22:1701-1712. [PubMed: 16197510]

Gines S, Bosch M, Marco S, Gavalda N, Diaz-Hernandez M, Lucas JJ, Canals JM, Alberch J. Reduced expression of the TrkB receptor in Huntington's disease mouse models and in human brain. Eur J Neurosci 2006;23:649-658. [PubMed: 16487146]

Gong S, Zheng C, Doughty ML, Losos K, Didkovsky N, Schambra UB, Nowak NJ, Joyner A, Leblanc G, Hatten ME, Heintz N. A gene expression atlas of the central nervous system based on bacterial artificial chromosomes. Nature 2003;425:917-925. [PubMed: 14586460]

Gottmann K, Mehrle A, Gisselmann G, Hatt H. Presynaptic control of subunit composition of NMDA receptors mediating synaptic plasticity. J Neurosci 1997;17:2766-2774. [PubMed: 9092598]

Graveland GA, Williams RS, DiFiglia M. Evidence for degenerative and regenerative changes in neostriatal spiny neurons in Huntington's disease. Science 1985;227:770-773. [PubMed: 3155875]

Gu X, Li C, Wei W, Lo V, Gong S, Li SH, Iwasato T, Itohara S, Li XJ, Mody I, Heintz N, Yang XW. Pathological cell-cell interactions elicited by a neuropathogenic form of mutant Huntingtin contribute to cortical pathogenesis in HD mice. Neuron 2005;46:433-444. [PubMed: 15882643] 
Guidetti P, Charles V, Chen EY, Reddy PH, Kordower JH, Whetsell WO Jr, Schwarcz R, Tagle DA. Early degenerative changes in transgenic mice expressing mutant huntingtin involve dendritic abnormalities but no impairment of mitochondrial energy production. Exp Neurol 2001;169:340350. [PubMed: 11358447]

Gutekunst CA, Li SH, Yi H, Mulroy JS, Kuemmerle S, Jones R, Rye D, Ferrante RJ, Hersch SM, Li XJ. Nuclear and neuropil aggregates in Huntington's disease: relationship to neuropathology. J Neurosci 1999;19:2522-2534. [PubMed: 10087066]

Halliday GM, McRitchie DA, Macdonald V, Double KL, Trent RJ, McCusker E. Regional specificity of brain atrophy in Huntington's disease. Exp Neurol 1998;154:663-672. [PubMed: 9878201]

Halpain S, Hipolito A, Saffer L. Regulation of F-actin stability in dendritic spines by glutamate receptors and calcineurin. J Neurosci 1998;18:9835-9844. [PubMed: 9822742]

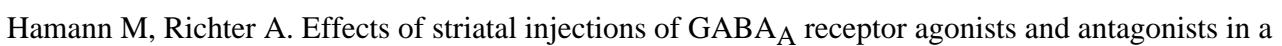
genetic animal model of paroxysmal dystonia. Eur J Pharmacol 2002;443:59-70. [PubMed: 12044793]

Hansson O, Petersén A, Leist M, Nicotera P, Castilho RF, Brundin P. Transgenic mice expressing a Huntington's disease mutation are resistant to quinolinic acid-induced striatal excitotoxicity. Proc Natl Acad Sci USA 1999;96:8727-8732. [PubMed: 10411943]

Hardingham GE, Fukunaga Y, Bading H. Extrasynaptic NMDARs oppose synaptic NMDARs by triggering CREB shut-off and cell death pathways. Nat Neurosci 2002;5:405-414. [PubMed: 11953750]

Harper, PS. Huntington's Disease. 2. W. B. Saunders; London: 1996.

Hedreen JC, Peyser CE, Folstein SE, Ross CA. Neuronal loss in layers V and VI of cerebral cortex in Huntington's disease. Neurosci Lett 1991;133:257-261. [PubMed: 1840078]

Hickey MA, Morton AJ. Mice transgenic for the Huntington's disease mutation are resistant to chronic 3-nitropropionic acid-induced striatal toxicity. J Neurochem 2000;75:2163-2171. [PubMed: 11032906]

Hickey MA, Chesselet MF. The use of transgenic and knock-in mice to study Huntington's disease. Cytogenet Genome Res 2003;100:276-286. [PubMed: 14526189]

Hickey MA, Reynolds GP, Morton AJ. The role of dopamine in motor symptoms in the R6/2 transgenic mouse model of Huntington's disease. J Neurochem 2002;81:46-59. [PubMed: 12067237]

Hickey MA, Gallant K, Gross GG, Levine MS, Chesselet MF. Early behavioral deficits in R6/2 mice suitable for use in preclinical drug testing. Neurobiol Dis 2005;20:1-11. [PubMed: 16137562]

Higgins DS, Hoyt KR, Baic C, Vensel J, Sulka M. Metabolic and glutamatergic disturbances in the Huntington's disease transgenic mouse. Ann N Y Acad Sci 1999;893:298-300. [PubMed: 10672253]

Hockly E, Cordery PM, Woodman B, Mahal A, van Dellen A, Blakemore C, Lewis CM, Hannan AJ, Bates GP. Environmental enrichment slows disease progression in R6/2 Huntington's disease mice. Ann Neurol 2002;51:235-242. [PubMed: 11835380]

Hodgson JG, Agopyan N, Gutekunst CA, Leavitt BR, LePiane F, Singaraja R, Smith DJ, Bissada N, McCutcheon K, Nasir J, Jamot L, Li XJ, Stevens ME, Rosemond E, Roder JC, Phillips AG, Rubin EM, Hersch SM, Hayden MR. A YAC mouse model for Huntington's disease with full-length mutant huntingtin, cytoplasmic toxicity, and selective striatal neurodegeneration. Neuron 1999;23:181-192. [PubMed: 10402204]

Hsu KS, Huang CC, Yang CH, Gean PW. Presynaptic D2 dopaminergic receptors mediate inhibition of excitatory synaptic transmission in rat neostriatum. Brain Res 1995;690:264-268. [PubMed: 8535848]

Huang CC, Lo SW, Hsu KS. Presynaptic mechanisms underlying cannabinoid inhibition of excitatory synaptic transmission in rat striatal neurons. J Physiol 2001;532:731-748. [PubMed: 11313442]

Huntington's Disease Collaborative Research Group. A novel gene containing a trinucleotide repeat that is expanded and unstable on Huntington's disease chromosomes. Cell 1993;72:971-983. [PubMed: 8458085]

Huntington Study Group. Dosage effects of riluzole in Huntington's disease: a multicenter placebocontrolled study. Neurology 2003;61:1551-1556. [PubMed: 14663041]

Jones, E. The Thalamus. Plenum Press; New York: 1987. 
Joshi PR, Gomez Y, Levine MS. Altered striatal AMPA receptor function in the R6/2 mouse model of Huntington's disease. Soc Neurosci Abstr. 2006In Press

Kartzinel R, Hunt RD, Calne DB. Bromocriptine in Huntington chorea. Arch Neurol 1976;33:517-518. [PubMed: 132915]

Kawaguchi Y, Wilson CJ, Augood SJ, Emson PC. Striatal interneurones: chemical, physiological and morphological characterization. Trends Neurosci 1995;18:527-535. [PubMed: 8638293]

Kemp JM, Powell TP. The termination of fibres from the cerebral cortex and thalamus upon dendritic spines in the caudate nucleus: a study with the Golgi method. Philos Trans R Soc Lond B Biol Sci 1971;262:429-439. [PubMed: 4107496]

Klapstein GJ, Levine MS. Age-dependent biphasic changes in ischemic sensitivity in the striatum of Huntington's disease R6/2 transgenic mice. J Neurophysiol 2005;93:758-765. [PubMed: 15371492]

Klapstein GJ, Fisher RS, Zanjani H, Cepeda C, Jokel ES, Chesselet MF, Levine MS. Electrophysiological and morphological changes in striatal spiny neurons in R6/2 Huntington's disease transgenic mice. J Neurophysiol 2001;86:2667-2677. [PubMed: 11731527]

Kubova H, Mares P. Effects of alprazolam on a model of human absences--rhythmic metrazol activity in rats. Physiol Res 1993;42:361-364. [PubMed: 8130184]

Kullmann DM, Asztely F. Extrasynaptic glutamate spillover in the hippocampus: evidence and implications. Trends Neurosci 1998;21:8-14. [PubMed: 9464678]

Lacey CJ, Boyes J, Gerlach O, Chen L, Magill PJ, Bolam JP. GABA $\mathrm{B}$ receptors at glutamatergic synapses in the rat striatum. Neuroscience 2005;136:1083-1095. [PubMed: 16226840]

Laforet GA, Sapp E, Chase K, McIntyre C, Boyce FM, Campbell M, Cadigan BA, Warzecki L, Tagle DA, Reddy PH, Cepeda C, Calvert CR, Jokel ES, Klapstein GJ, Ariano MA, Levine MS, DiFiglia $\mathrm{M}$, Aronin N. Changes in cortical and striatal neurons predict behavioral and electrophysiological abnormalities in a transgenic murine model of Huntington's disease. J Neurosci 2001;21:91129123. [PubMed: 11717344]

Landwehrmeyer GB, McNeil SM, Dure LS IV, Ge P, Aizawa H, Huang Q, Ambrose CM, Duyao MP, Bird ED, Bonilla E, de Young M, Avila-Gonzales AJ, Wexler NS, DiFiglia M, Gusella JF, MacDonald ME, Penney JB, Young AB, Vonsattel JP. Huntington's disease gene: regional and cellular expression in brain of normal and affected individuals. Ann Neurol 1995a;37:218-230. [PubMed: 7847863]

Landwehrmeyer GB, Standaert DG, Testa CM, Penny JB Jr, Young AB. NMDA receptor subunit mRNA expression by projection neurons and interneurons in rat striatum. J Neurosci 1995b;15:5297-5307. [PubMed: 7623152]

Lapper SR, Bolam JP. Input from the frontal cortex and the parafascicular nucleus to cholinergic interneurons in the dorsal striatum of the rat. Neuroscience 1992;51:533-545. [PubMed: 1488113]

Lastres-Becker I, Berrendero F, Lucas JJ, Martin-Aparicio E, Yamamoto A, Ramos JA, Fernandez-Ruiz JJ. Loss of mRNA levels, binding and activation of GTP-binding proteins for cannabinoid CB1 receptors in the basal ganglia of a transgenic model of Huntington's disease. Brain Res 2002;929:236-242. [PubMed: 11864629]

Lastres-Becker I, Bizat N, Boyer F, Hantraye P, Brouillet E, Fernandez-Ruiz J. Effects of cannabinoids in the rat model of Huntington's disease generated by an intrastriatal injection of malonate. Neuroreport 2003;14:813-816. [PubMed: 12858038]

Lei W, Jiao Y, Del Mar N, Reiner A. Evidence for differential cortical input to direct pathway versus indirect pathway striatal projection neurons in rats. J Neurosci 2004;24:8289-8299. [PubMed: 15385612]

Levine MS, Klapstein GJ, Koppel A, Gruen E, Cepeda C, Vargas ME, Jokel ES, Carpenter EM, Zanjani H, Hurst RS, Efstratiadis A, Zeitlin S, Chesselet MF. Enhanced sensitivity to N-methyl-D-aspartate receptor activation in transgenic and knockin mouse models of Huntington's disease. J Neurosci Res 1999;58:515-532. [PubMed: 10533044]

Levine MS, Cepeda C, Hickey MA, Fleming SM, Chesselet MF. Genetic mouse models of Huntington's and Parkinson's diseases: illuminating but imperfect. Trends Neurosci 2004;27:691-697. [PubMed: 15474170] 
Levine MS, Wu N, Cepeda C, Leavitt BR, Hayden MR. Alterations in corticostriatal synaptic responses in mouse models of Huntington's disease. Soc Neurosci Abstr. 2005Program No. 90.10

Li H, Li SH, Cheng AL, Mangiarini L, Bates GP, Li XJ. Ultrastructural localization and progressive formation of neuropil aggregates in Huntington's disease transgenic mice. Hum Mol Genet 1999;8:1227-1236. [PubMed: 10369868]

Li H, Li SH, Johnston H, Shelbourne PF, Li XJ. Amino-terminal fragments of mutant huntingtin show selective accumulation in striatal neurons and synaptic toxicity. Nat Genet 2000;25:385-389. [PubMed: 10932179]

Li H, Wyman T, Yu ZX, Li SH, Li XJ. Abnormal association of mutant huntingtin with synaptic vesicles inhibits glutamate release. Hum Mol Genet 2003;12:2021-2030. [PubMed: 12913073]

Li JY, Plomann M, Brundin P. Huntington's disease: a synaptopathy. Trends Mol Med 2003;9:414-420. [PubMed: 14557053]

Li L, Fan M, Icton CD, Chen N, Leavitt BR, Hayden MR, Murphy TH, Raymond LA. Role of NR2Btype NMDA receptors in selective neurodegeneration in Huntington disease. Neurobiol Aging 2003;24:1113-1121. [PubMed: 14643383]

Li L, Murphy TH, Hayden MR, Raymond LA. Enhanced striatal NR2B containing N-methyl-D-aspartate receptor-mediated synaptic currents in a mouse model of Huntington disease. J Neurophysiol 2004;92:2738-2746. [PubMed: 15240759]

Li SH, Gutekunst CA, Hersch SM, Li XJ. Interaction of huntingtin-associated protein with dynactin P150Glued. J Neurosci 1998;18:1261-1269. [PubMed: 9454836]

Li YX, Zhang Y, Lester HA, Schuman EM, Davidson N. Enhancement of neurotransmitter release induced by brain-derived neurotrophic factor in cultured hippocampal neurons. J Neurosci 1998;18:10231-10240. [PubMed: 9852560]

Liévens JC, Woodman B, Mahal A, Spasic-Boscovic O, Samuel D, Kerkerian-Le Goff L, Bates GP. Impaired glutamate uptake in the R6 Huntington's disease transgenic mice. Neurobiol Dis 2001;8:807-821. [PubMed: 11592850]

Liévens JC, Woodman B, Mahal A, Bates GP. Abnormal phosphorylation of synapsin I predicts a neuronal transmission impairment in the R6/2 Huntington's disease transgenic mice. Mol Cell Neurosci 2002;20:638-648. [PubMed: 12213445]

Lin CH, Tallaksen-Greene S, Chien WM, Cearley JA, Jackson WS, Crouse AB, Ren S, Li XJ, Albin RL, Detloff PJ. Neurological abnormalities in a knock-in mouse model of Huntington's disease. Hum Mol Genet 2001;10:137-144. [PubMed: 11152661]

Lione LA, Carter RJ, Hunt MJ, Bates GP, Morton AJ, Dunnett SB. Selective discrimination learning impairments in mice expressing the human Huntington's disease mutation. J Neurosci 1999;19:10428-10437. [PubMed: 10575040]

Loeb C, Roccatagliata G, Albano C, Besio G. Bromocriptine and dopaminergic function in Huntington disease. Neurology 1979;29:730-734. [PubMed: 155784]

Lovinger DM, Choi S. Activation of adenosine A1 receptors initiates short-term synaptic depression in rat striatum. Neurosci Lett 1995;199:9-12. [PubMed: 8584233]

Lovinger DM, McCool BA. Metabotropic glutamate receptor-mediated presynaptic depression at corticostriatal synapses involves mGLuR2 or 3. J Neurophysiol 1995;73:1076-1083. [PubMed: 7608756]

Lovinger DM, Tyler E, Fidler S, Merritt A. Properties of a presynaptic metabotropic glutamate receptor in rat neostriatal slices. J Neurophysiol 1993;69:1236-1244. [PubMed: 8388042]

Lozovaya NA, Kopanitsa MV, Boychuk YA, Krishtal OA. Enhancement of glutamate release uncovers spillover-mediated transmission by N-methyl-D-aspartate receptors in the rat hippocampus. Neuroscience 1999;91:1321-1330. [PubMed: 10391439]

Luthi-Carter R, Strand A, Peters NL, Solano SM, Hollingsworth ZR, Menon AS, Frey AS, Spektor BS, Penney EB, Schilling G, Ross CA, Borchelt DR, Tapscott SJ, Young AB, Cha JH, Olson JM. Decreased expression of striatal signaling genes in a mouse model of Huntington's disease. Hum Mol Genet 2000;9:1259-1271. [PubMed: 10814708]

MacDonald V, Halliday G. Pyramidal cell loss in motor cortices in Huntington's disease. Neurobiol Dis 2002;10:378-386. [PubMed: 12270698] 
MacGibbon GA, Hamilton LC, Crocker SF, Costain WJ, Murphy KM, Robertson HA, Denovan-Wright EM. Immediate-early gene response to methamphetamine, haloperidol, and quinolinic acid is not impaired in Huntington's disease transgenic mice. J Neurosci Res 2002;67:372-378. [PubMed: 11813242]

Mahon S, Deniau JM, Charpier S. Corticostriatal plasticity: life after the depression. Trends Neurosci 2004;27:460-467. [PubMed: 15271493]

Malenka RC, Kocsis JD. Presynaptic actions of carbachol and adenosine on corticostriatal synaptic transmission studied in vitro. J Neurosci 1988;8:3750-3756. [PubMed: 2848109]

Mangiarini L, Sathasivam K, Seller M, Cozens B, Harper A, Hetherington C, Lawton M, Trottier Y, Lehrach H, Davies SW, Bates GP. Exon 1 of the HD gene with an expanded CAG repeat is sufficient to cause a progressive neurological phenotype in transgenic mice. Cell 1996;87:493-506. [PubMed: 8898202]

Mary V, Wahl F, Stutzmann JM. Effect of riluzole on quinolinate-induced neuronal damage in rats: comparison with blockers of glutamatergic neurotransmission. Neurosci Lett 1995;201:92-96. [PubMed: 8830323]

McCaw EA, Hu H, Gomez GT, Hebb AL, Kelly ME, Denovan-Wright EM. Structure, expression and regulation of the cannabinoid receptor gene (CB1) in Huntington's disease transgenic mice. Eur J Biochem 2004;271:4909-4920. [PubMed: 15606779]

McGeer EG, McGeer PL, Singh K. Kainate-induced degeneration of neostriatal neurons: dependency upon corticostriatal tract. Brain Res 1978;139:381-383. [PubMed: 146535]

Menalled LB, Chesselet MF. Mouse models of Huntington's disease. Trends Pharmacol Sci 2002;23:3239. [PubMed: 11804649]

Menalled L, Zanjani H, MacKenzie L, Koppel A, Carpenter E, Zeitlin S, Chesselet MF. Decrease in striatal enkephalin mRNA in mouse models of Huntington's disease. Exp Neurol 2000;162:328342. [PubMed: 10739639]

Menalled LB, Sison JD, Wu Y, Olivieri M, Li XJ, Li H, Zeitlin S, Chesselet MF. Early motor dysfunction and striosomal distribution of huntingtin microaggregates in Huntington's disease knock-in mice. J Neurosci 2002;22:8266-8276. [PubMed: 12223581]

Menalled LB, Sison JD, Dragatsis I, Zeitlin S, Chesselet MF. Time course of early motor and neuropathological anomalies in a knock-in mouse model of Huntington's disease with $140 \mathrm{CAG}$ repeats. J Comp Neurol 2003;465:11-26. [PubMed: 12926013]

Milnerwood AJ, Cummings DM, Dallerac GM, Brown JY, Vatsavayai SC, Hirst MC, Rezaie P, Murphy KP. Early development of aberrant synaptic plasticity in a mouse model of Huntington's disease. Hum Mol Genet 2006;15:1690-1703. [PubMed: 16600988]

Mitchell IJ, Cooper AJ, Griffiths MR. The selective vulnerability of striatopallidal neurons. Prog Neurobiol 1999;59:691-719. [PubMed: 10845758]

Mizuta I, Ohta M, Ohta K, Nishimura M, Mizuta E, Kuno S. Riluzole stimulates nerve growth factor, brain-derived neurotrophic factor and glial cell line-derived neurotrophic factor synthesis in cultured mouse astrocytes. Neurosci Lett 2001;310:117-120. [PubMed: 11585581]

Morton AJ, Leavens W. Mice transgenic for the human Huntington's disease mutation have reduced sensitivity to kainic acid toxicity. Brain Res Bull 2000;52:51-59. [PubMed: 10779703]

Morton AJ, Lagan MA, Skepper JN, Dunnett SB. Progressive formation of inclusions in the striatum and hippocampus of mice transgenic for the human Huntington's disease mutation. J Neurocytol 2000;29:679-702. [PubMed: 11353291]

Morton AJ, Edwardson JM. Progressive depletion of complexin II in a transgenic mouse model of Huntington's disease. J Neurochem 2001;76:166-172. [PubMed: 11145989]

Morton AJ, Faull RL, Edwardson JM. Abnormalities in the synaptic vesicle fusion machinery in Huntington's disease. Brain Res Bull 2001;56:111-117. [PubMed: 11704347]

Murphy KP, Carter RJ, Lione LA, Mangiarini L, Mahal A, Bates GP, Dunnett SB, Morton AJ. Abnormal synaptic plasticity and impaired spatial cognition in mice transgenic for exon 1 of the human Huntington's disease mutation. J Neurosci 2000;20:5115-5123. [PubMed: 10864968]

Naver B, Stub C, Moller M, Fenger K, Hansen AK, Hasholt L, Sorensen SA. Molecular and behavioral analysis of the R6/1 Huntington's disease transgenic mouse. Neuroscience 2003;122:1049-1057. [PubMed: 14643771] 
NicNiocaill B, Haraldsson B, Hansson O, O’Connor WT, Brundin P. Altered striatal amino acid neurotransmitter release monitored using microdialysis in R6/1 Huntington transgenic mice. Eur $J$ Neurosci 2001;13:206-210. [PubMed: 11135020]

Nisenbaum ES, Berger TW, Grace AA. Presynaptic modulation by GABAB receptors of glutamatergic excitation and GABAergic inhibition of neostriatal neurons. J Neurophysiol 1992;67:477-481. [PubMed: 1349038]

Nisenbaum ES, Wilson CJ. Potassium currents responsible for inward and outward rectification in rat neostriatal spiny projection neurons. J Neurosci 1995;15:4449-4463. [PubMed: 7790919]

Orlando LR, Standaert DG, Penney JB Jr, Young AB. Metabotropic receptors in excitotoxicity: (S)-4carboxy-3-hydroxyphenylglycine ((S)-4C3HPG) protects against rat striatal quinolinic acid lesions. Neurosci Lett 1995;202:109-112. [PubMed: 8787843]

Orlando LR, Alsdorf SA, Penney JB Jr, Young AB. The role of group I and group II metabotropic glutamate receptors in modulation of striatal NMDA and quinolinic acid toxicity. Exp Neurol 2001;167:196-204. [PubMed: 11161608]

Pang TY, Stam NC, Nithianantharajah J, Howard ML, Hannan AJ. Differential effects of voluntary physical exercise on behavioral and brain-derived neurotrophic factor expression deficits in huntington's disease transgenic mice. Neuroscience 2006;141:569-584. [PubMed: 16716524]

Perez-Navarro E, Canudas AM, Akerund P, Alberch J, Arenas E. Brain-derived neurotrophic factor, neurotrophin-3, and neurotrophin-4/5 prevent the death of striatal projection neurons in a rodent model of Huntington's disease. J Neurochem 2000;75:2190-2199. [PubMed: 11183872]

Perutz MF. Glutamine repeats and neurodegenerative diseases: molecular aspects. Trends Biochem Sci 1999;24:58-63. [PubMed: 10098399]

Petersén A, Hansson O, Puschban Z, Sapp E, Romero N, Castilho RF, Sulzer D, Rice M, DiFiglia M, Przedborski S, Brundin P. Mice transgenic for exon 1 of the Huntington's disease gene display reduced striatal sensitivity to neurotoxicity induced by dopamine and 6-hydroxydopamine. Eur J Neurosci 2001;14:1425-1435. [PubMed: 11722604]

Petersén A, Chase K, Puschban Z, DiFiglia M, Brundin P, Aronin N. Maintenance of susceptibility to neurodegeneration following intrastriatal injections of quinolinic acid in a new transgenic mouse model of Huntington's disease. Exp Neurol 2002;175:297-300. [PubMed: 12009780]

Petersén A, Gil J, Maat-Schieman ML, Bjorkqvist M, Tanila H, Araujo IM, Smith R, Popovic N, Wierup N, Norlen P, Li JY, Roos RA, Sundler F, Mulder H, Brundin P. Orexin loss in Huntington's disease. Hum Mol Genet 2005;14:39-47. [PubMed: 15525658]

Picconi B, Passino E, Sgobio C, Bonsi P, Barone I, Ghiglieri V, Pisani A, Bernardi G, Ammassari-Teule M, Calabresi P. Plastic and behavioral abnormalities in experimental Huntington's disease: a crucial role for cholinergic interneurons. Neurobiol Dis 2006;22:143-152. [PubMed: 16326108]

Plotkin JL, Wu N, Chesselet MF, Levine MS. Functional and molecular development of striatal fastspiking GABAergic interneurons and their cortical inputs. Eur J Neurosci 2005;22:1097-1108. [PubMed: 16176351]

Plotkin JL, Levine MS. $\mathrm{Ca}^{2+}$ dynamics in the striatum of the R6/2 mouse model of Huntington's disease. Soc Neurosci Abstr. 2006In Press

Popoli P, Pintor A, Domenici MR, Frank C, Tebano MT, Pezzola A, Scarchilli L, Quarta D, Reggio R, Malchiodi-Albedi F, Falchi M, Massotti M. Blockade of striatal adenosine A2A receptor reduces, through a presynaptic mechanism, quinolinic acid-induced excitotoxicity: possible relevance to neuroprotective interventions in neurodegenerative diseases of the striatum. J Neurosci 2002;22:1967-1975. [PubMed: 11880527]

Quinn N, Marsden CD. A double blind trial of sulpiride in Huntington's disease and tardive dyskinesia. J Neurol Neurosurg Psychiatry 1984;47:844-847. [PubMed: 6236286]

Rasmussen A, Macias R, Yescas P, Ochoa A, Davila G, Alonso E. Huntington disease in children: genotype-phenotype correlation. Neuropediatrics 2000;31:190-194. [PubMed: 11071143]

Rebec GV, Conroy SK, Barton SJ. Hyperactive striatal neurons in symptomatic Huntington R6/2 mice: variations with behavioral state and repeated ascorbate treatment. Neuroscience 2006;137:327-336. [PubMed: 16257492]

Reiner A. Can lesions of GPe correct HD deficits? Exp Neurol 2004;186:1-5. [PubMed: 14980805] 
Reiner A, Albin RL, Anderson KD, D'Amato CJ, Penney JB, Young AB. Differential loss of striatal projection neurons in Huntington disease. Proc Natl Acad Sci USA 1988;85:5733-5737. [PubMed: 2456581]

Richfield EK, Maguire-Zeiss KA, Vonkeman HE, Voorn P. Preferential loss of preproenkephalin versus preprotachykinin neurons from the striatum of Huntington's disease patients. Ann Neurol 1995;38:852-861. [PubMed: 8526457]

Rosas HD, Koroshetz WJ, Jenkins BG, Chen YI, Hayden DL, Beal MF, Cudkowicz ME. Riluzole therapy in Huntington's disease (HD). Mov Disord 1999;14:326-330. [PubMed: 10091628]

Rosas HD, Liu AK, Hersch S, Glessner M, Ferrante RJ, Salat DH, van der Kouwe A, Jenkins BG, Dale AM, Fischl B. Regional and progressive thinning of the cortical ribbon in Huntington's disease. Neurology 2002;58:695-701. [PubMed: 11889230]

Rubinsztein DC. Lessons from animal models of Huntington's disease. Trends Genet 2002;18:202-209. [PubMed: 11932021]

Sapp E, Ge P, Aizawa H, Bird E, Penney J, Young AB, Vonsattel JP, DiFiglia M. Evidence for a preferential loss of enkephalin immunoreactivity in the external globus pallidus in low grade Huntington's disease using high resolution image analysis. Neuroscience 1995;64:397-404. [PubMed: 7535402]

Sapp E, Penney J, Young AB, Aronin N, Vonsattel JP, DiFiglia M. Axonal transport of N-terminal huntingtin suggests early pathology of corticostriatal projections in Huntington disease. $\mathrm{J}$ Neuropathol Exp Neurol 1999;58:165-173. [PubMed: 10029099]

Sattler R, Xiong Z, Lu WY, MacDonald JF, Tymianski M. Distinct roles of synaptic and extrasynaptic NMDA receptors in excitotoxicity. J Neurosci 2000;20:22-33. [PubMed: 10627577]

Schiefer J, Alberty A, Dose T, Oliva S, Noth J, Kosinski CM. Huntington's disease transgenic mice are resistant to global cerebral ischemia. Neurosci Lett 2002a;334:99-102. [PubMed: 12435481]

Schiefer J, Landwehrmeyer GB, Luesse HG, Sprunken A, Puls C, Milkereit A, Milkereit E, Kosinski $\mathrm{CM}$. Riluzole prolongs survival time and alters nuclear inclusion formation in a transgenic mouse model of Huntington's disease. Mov Disord 2002b;17:748-757. [PubMed: 12210870]

Schiefer J, Sprunken A, Puls C, Luesse HG, Milkereit A, Milkereit E, Johann V, Kosinski CM. The metabotropic glutamate receptor 5 antagonist MPEP and the mGluR2 agonist LY379268 modify disease progression in a transgenic mouse model of Huntington's disease. Brain Res 2004;1019:246-254. [PubMed: 15306259]

Schrott LM. Effect of training and environment on brain morphology and behavior. Acta Paediatr Suppl 1997;422:45-47. [PubMed: 9298792]

Segal M. Dendritic spines for neuroprotection: a hypothesis. Trends Neurosci 1995;18:468-471. [PubMed: 8592749]

Shehadeh J, Fernandes HB, Zeron-Mullins MM, Graham RK, Leavitt BR, Hayden MR, Raymond LA. Striatal neuronal apoptosis is preferentially enhanced by NMDA receptor activation in YAC transgenic mouse model of Huntington disease. Neurobiol Dis 2006;21:392-403. [PubMed: 16165367]

Shelbourne PF, Killeen N, Hevner RF, Johnston HM, Tecott L, Lewandoski M, Ennis M, Ramirez L, Li Z, Iannicola C, Littman DR, Myers RM. A Huntington's disease CAG expansion at the murine Hdh locus is unstable and associated with behavioural abnormalities in mice. Hum Mol Genet 1999;8:763-774. [PubMed: 10196365]

Shoulson I, Goldblatt D, Charlton M, Joynt RJ. Huntington's disease: treatment with muscimol, a GABAmimetic drug. Ann Neurol 1978;4:279-284. [PubMed: 152602]

Shoulson I, Odoroff C, Oakes D, Behr J, Goldblatt D, Caine E, Kennedy J, Miller C, Bamford K, Rubin A, Plumb S, Kurlan R. A controlled clinical trial of baclofen as protective therapy in early Huntington's disease. Ann Neurol 1989;25:252-259. [PubMed: 2524992]

Sieradzan KA, Mann DM. The selective vulnerability of nerve cells in Huntington's disease. Neuropathol Appl Neurobiol 2001;27:1-21. [PubMed: 11298997]

Slow EJ, van Raamsdonk J, Rogers D, Coleman SH, Graham RK, Deng Y, Oh R, Bissada N, Hossain SM, Yang YZ, Li XJ, Simpson EM, Gutekunst CA, Leavitt BR, Hayden MR. Selective striatal neuronal loss in a YAC128 mouse model of Huntington disease. Hum Mol Genet 2003;12:15551567. [PubMed: 12812983]

Prog Neurobiol. Author manuscript; available in PMC 2007 July 10. 
Slow EJ, Graham RK, Hayden MR. To be or not to be toxic: aggregations in Huntington and Alzheimer disease. Trends Genet. 2006Jun 25 [Epub ahead of print]

Smith AD, Bolam JP. The neural network of the basal ganglia as revealed by the study of synaptic connections of identified neurones. Trends Neurosci 1990;13:259-265. [PubMed: 1695400]

Smith AD, Zigmond MJ. Can the brain be protected through exercise? Lessons from an animal model of parkinsonism. Exp Neurol 2003;184:31-39. [PubMed: 14637076]

Smith Y, Bevan MD, Shink E, Bolam JP. Microcircuitry of the direct and indirect pathways of the basal ganglia. Neurosci 1998;86:353-387.

Smith R, Musleh W, Akopian G, Buckwalter G, Walsh JP. Regional differences in the expression of corticostriatal synaptic plasticity. Neuroscience 2001;106:95-101. [PubMed: 11564420]

Smith R, Brundin P, Li JY. Synaptic dysfunction in Huntington's disease: a new perspective. Cell Mol Life Sci 2005a;62:1901-1912. [PubMed: 15968465]

Smith R, Petersen A, Bates GP, Brundin P, Li JY. Depletion of rabphilin 3A in a transgenic mouse model (R6/1) of Huntington's disease, a possible culprit in synaptic dysfunction. Neurobiol Dis 2005b; 20:673-684. [PubMed: 15967669]

Sotrel A, Paskevich PA, Kiely DK, Bird ED, Williams RS, Myers RH. Morphometric analysis of the prefrontal cortex in Huntington's disease. Neurology 1991;41:1117-1123. [PubMed: 1829794]

Spencer JP, Murphy KP. Bi-directional changes in synaptic plasticity induced at corticostriatal synapses in vitro. Exp Brain Res 2000;135:497-503. [PubMed: 11156313]

Spires TL, Grote HE, Garry S, Cordery PM, Van Dellen A, Blakemore C, Hannan AJ. Dendritic spine pathology and deficits in experience-dependent dendritic plasticity in R6/1 Huntington's disease transgenic mice. Eur J Neurosci 2004;19:2799-2807. [PubMed: 15147313]

Standaert DG, Friberg IK, Landwehrmeyer GB, Young AB, Penney JB Jr. Expression of NMDA glutamate receptor subunit mRNAs in neurochemically identified projection and interneurons in the striatum of the rat. Brain Res Mol Brain Res 1999;64:11-23. [PubMed: 9889300]

Starling AJ, André VM, Cepeda C, de Lima M, Chandler SH, Levine MS. Alterations in N-methyl-Daspartate receptor sensitivity and magnesium blockade occur early in development in the R6/2 mouse model of Huntington's disease. J Neurosci Res 2005;82:377-386. [PubMed: 16211559]

Strong TV, Tagle DA, Valdes JM, Elmer LW, Boehm K, Swaroop M, Kaatz KW, Collins FS, Albin RL. Widespread expression of the human and rat Huntington's disease gene in brain and nonneural tissues. Nat Genet 1993;5:259-265. [PubMed: 8275091]

Sun Y, Savanenin A, Reddy PH, Liu YF. Polyglutamine-expanded huntingtin promotes sensitization of N-methyl-D- aspartate receptors via post-synaptic density 95. J Biol Chem 2001;276:24713-24718. [PubMed: 11319238]

Surmeier DJ, Song WJ, Yan Z. Coordinated expression of dopamine receptors in neostriatal medium spiny neurons. J Neurosci 1996;16:6579-91. [PubMed: 8815934]

Swayne LA, Chen L, Hameed S, Barr W, Charlesworth E, Colicos MA, Zamponi GW, Braun JE. Crosstalk between huntingtin and syntaxin 1A regulates N-type calcium channels. Mol Cell Neurosci 2005;30:339-351. [PubMed: 16162412]

Tabrizi SJ, Workman J, Hart PE, Mangiarini L, Mahal A, Bates G, Cooper JM, Schapira AH. Mitochondrial dysfunction and free radical damage in the Huntington R6/2 transgenic mouse. Ann Neurol 2000;47:80-86. [PubMed: 10632104]

Tanaka T, Saito H, Matsuki N. Inhibition of $\mathrm{GABA}_{\mathrm{A}}$ synaptic responses by brain-derived neurotrophic factor (BDNF) in rat hippocampus. J Neurosci 1997;17:2959-2966. [PubMed: 9096132]

Tarditi A, Camurri A, Varani K, Borea PA, Woodman B, Bates G, Cattaneo E, Abbracchio MP. Early and transient alteration of adenosine A2A receptor signaling in a mouse model of Huntington disease. Neurobiol Dis 2006;23:44-53. [PubMed: 16651003]

Tobin AJ, Signer ER. Huntington's disease: the challenge for cell biologists. Trends Cell Biol 2000;10:531-536. [PubMed: 11121745]

Tovar KR, Westbrook GL. The incorporation of NMDA receptors with a distinct subunit composition at nascent hippocampal synapses in vitro. J Neurosci 1999;19:4180-188. [PubMed: 10234045]

Turmaine M, Raza A, Mahal A, Mangiarini L, Bates GP, Davies SW. Nonapoptotic neurodegeneration in a transgenic mouse model of Huntington's disease. Proc Natl Acad Sci USA 2000;97:8093-8097. [PubMed: 10869421] 
Uhl GR, Navia B, Douglas J. Differential expression of preproenkephalin and preprodynorphin mRNAs in striatal neurons: high levels of preproenkephalin expression depend on cerebral cortical afferents. J Neurosci 1988;8:4755-4764. [PubMed: 2904494]

Usdin MT, Shelbourne PF, Myers RM, Madison DV. Impaired synaptic plasticity in mice carrying the Huntington's disease mutation. Hum Mol Genet 1999;8:839-846. [PubMed: 10196373]

Uzgil B, Cepeda C, Wu N, Buchwald NA, Levine MS. Increased cortical excitability in the R6/2 mouse model of Huntington's disease. Soc Neurosci Abst 2004;30:564.2.

van Dellen A, Blakemore C, Deacon R, York D, Hannan AJ. Delaying the onset of Huntington's in mice. Nature 2000;404:721-722. [PubMed: 10783874]

Vonsattel JP, DiFiglia M. Huntington disease. J Neuropathol Exp Neurol 1998;57:369-384. [PubMed: 9596408]

Vonsattel JP, Meyers RH, Stevens TJ, Ferrante RJ, Bird ED, Richardson EP Jr. Neuropathological classification of Huntington's disease. J Neuropathol Exp Neurol 1985;44:559-577. [PubMed: 2932539]

Waddington JL, Cross AJ. Therapeutic failure of GABA agonist treatment in Huntington's disease. Neurology 1984;34:702. [PubMed: 6231490]

Wheeler VC, White JK, Gutekunst CA, Vrbanac V, Weaver M, Li XJ, Li SH, Yi H, Vonsattel JP, Gusella JF, Hersch S, Auerbach W, Joyner AL, MacDonald ME. Long glutamine tracts cause nuclear localization of a novel form of huntingtin in medium spiny striatal neurons in HdhQ92 and HdhQ111 knock-in mice. Hum Mol Genet 2000;9:503-513. [PubMed: 10699173]

White JK, Auerbach W, Duyao MP, Vonsattel JP, Gusella JF, Joyner AL, MacDonald ME. Huntingtin is required for neurogenesis and is not impaired by the Huntington's disease CAG expansion. Nat Genet 1997;17:404-410. [PubMed: 9398841]

Wilson CJ, Kawaguchi Y. The origins of two-state spontaneous membrane potential fluctuations of neostriatal spiny neurons. J Neurosci 1996;16:2397-2410. [PubMed: 8601819]

Wong PT, McGeer PL, Rossor M, McGeer EG. Ornithine aminotransferase in Huntington's disease. Brain Res 1982;231:466-471. [PubMed: 6459816]

Wood JD, MacMillan JC, Harper PS, Lowenstein PR, Jones AL. Partial characterisation of murine huntingtin and apparent variations in the subcellular localisation of huntingtin in human, mouse and rat brain. Hum Mol Genet 1996;5:481-487. [PubMed: 8845840]

Wu N, Starling AJ, Cepeda C, Levine MS. Striatal synaptically-evoked currents in a mouse model of Huntington's disease. Soc Neurosci Abstr. 2004Program No. 564.10

Wüllner U, Young AB, Penny JB, Beal MF. 3-Nitropropionic acid toxicity in the striatum. J Neurochem 1994;63:1772-1781. [PubMed: 7523600]

Yamamoto A, Lucas JJ, Hen R. Reversal of neuropathology and motor dysfunction in a conditional model of Huntington's disease. Cell 2000;101:57-66. [PubMed: 10778856]

Yin HH, Lovinger DM. Frequency-specific and D2 receptor-mediated inhibition of glutamate release by retrograde endocannabinoid signaling. Proc Natl Acad Sci USA 2006;103:8251-8256. [PubMed: 16698932]

Young AB. Huntingtin in health and disease. J Clin Invest 2003;111:299-302. [PubMed: 12569151]

Zeron MM, Hansson O, Chen N, Wellington CL, Leavitt BR, Brundin P, Hayden MR, Raymond LA. Increased sensitivity to N-methyl-D-aspartate receptor-mediated excitotoxicity in a mouse model of Huntington's disease. Neuron 2002;33:849-860. [PubMed: 11906693]

Zuccato C, Ciammola A, Rigamonti D, Leavitt BR, Goffredo D, Conti L, MacDonald ME, Friedlander RM, Silani V, Hayden MR, Timmusk T, Sipione S, Cattaneo E. Loss of huntingtin-mediated BDNF gene transcription in Huntington's disease. Science 2001;293:493-498. [PubMed: 11408619]

Zuccato C, Liber D, Ramos C, Tarditi A, Rigamonti D, Tartari M, Valenza M, Cattaneo E. Progressive loss of BDNF in a mouse model of Huntington's disease and rescue by BDNF delivery. Pharmacol Res 2005;52:133-139. [PubMed: 15967378]

Zuchora B, Turski WA, Wielosz M, Urbanska EM. Protective effect of adenosine receptor agonists in a new model of epilepsy--seizures evoked by mitochondrial toxin, 3-nitropropionic acid, in mice. Neurosci Lett 2001;305:91-94. [PubMed: 11376891] 


\section{Abbreviations}

HD

Huntington's disease

CAG

(cytosine adenine guanine) DNA triplet sequence coding for glutamine

YAC

yeast artificial chromosome

$\operatorname{Tg}$

transgenic

MSSN

medium-sized spiny neuron

NMDA

N-methyl-D-aspartate

AMPA

a-amino-3-hydroxy-5-methyl-4-isoxazolepropionic acid

D1

dopamine D1 receptor subtype

D2

dopamine $\mathrm{D} 2$ receptor subtype

$\mathbf{A}_{1}$

adenosine 1 receptor subtype

$\mathbf{A}_{\mathbf{2 A}}$

adenosine $2 \mathrm{~A}$ receptor subtype

mGluR $_{2 / 3}$

group II metabotropic glutamate receptor subtypes

mGluR $_{5}$

group I metabotropic glutamate receptor

$\mathrm{CB}_{1}$

cannabinoid 1 receptor subtype

GABA

$\gamma$-aminobutyric acid

GABA $_{A}$ and GABA $_{B}$

ionotropic and metabotropic GABA receptor subtypes

Kir2.1 and 2.3

inwardly rectifying potassium channels

Kv2.1

voltage-activated potassium channel underlying delayed rectification

HVA

high voltage-activated

Prog Neurobiol. Author manuscript; available in PMC 2007 July 10. 
EPSP

excitatory postsynaptic potential

NR1 and NR2A/B

$\mathrm{N}$-methyl-D-aspartate receptor subunits

GluR6

glutamate receptor subunit constitutive of kainate receptors

3-NP

3-nitropropionic acid

BDNF

brain derived neurotrophic factor

TrkB

tyrosine kinase receptor subtype that binds neurotrophins, in particular BDNF

EGFP

enhanced green fluorescent protein

RT-PCR

reverse transcriptase polymerase chain reaction

ADAC

adenosine amine congener, a selective $\mathrm{A}_{1}$ adenosine receptor agonist

CGS21680

a selective $\mathrm{A}_{2 \mathrm{~A}}$ adenosine receptor agonist

L-DOPA

levodopa, metabolic precursor of dopamine

PSD95

postsynaptic density 95

CREB

cAMP response element binding protein

LTD

long-term depression

LTP

long-term potentiation 